\title{
BEST
}

\section{BILINGUAL ENVIRONMENTAL}

\section{SCIENCE TRAINING}

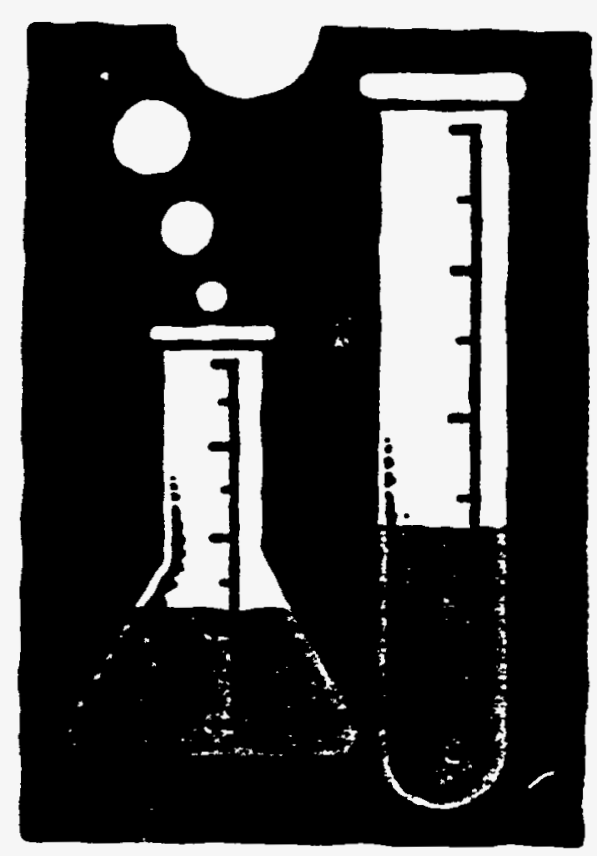

GRADES 5 - 6

ACTIVITIES TO DO AT HOME 



\title{
BEST
}

\section{BILINGUAL ENVIRONMENTAL}

\author{
SCIENCE TRAINING
}

\section{GRADES 5 - 6}

\section{DISCLAIMER}

This report was prepared as an account of work sponsored by an agency of the United States Government. Neither the United States Government nor any agency thereof, nor any of their employees, makes any warranty, express or implied, or assumes any legal liability or responsibility for the accuracy, completeness, or usefulness of any information, apparatus, product, or process disclosed, or represents that its use would not infringe privately owned rights. Reference herein to any specific commercial product, process, or service by trade name, trademark, manufacturer, or otherwise does not necessarily constitute or imply its endorsement, recommendation, or favoring by the United States Government or any agency thereof. The views and opinions of authors expressed herein do not necessarily state or reflect those of the United States Government or any agency thereof.

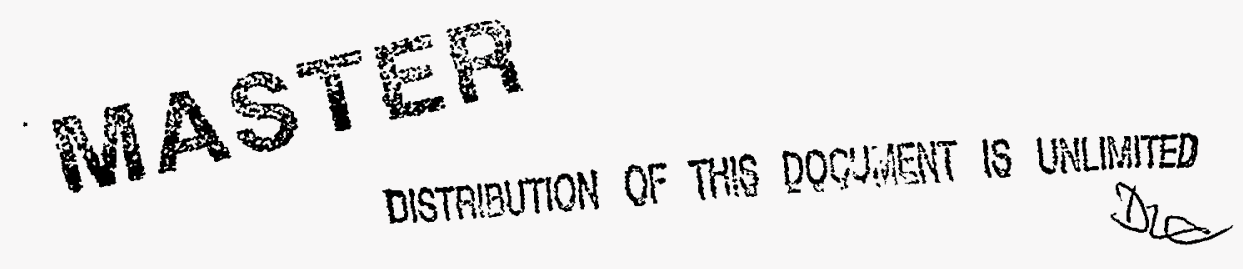





\section{OBSERVATION}

LESSON 1--CHEMICAL CHANGES $\ldots \ldots \ldots \ldots \ldots \ldots \ldots \ldots$

PREFACE FOR PLANT EXPERIMENTS $\ldots \ldots \ldots \ldots \ldots \ldots$

LESSON 2--LIVING THINGS - PLANTS $\ldots \ldots \ldots \ldots \ldots \ldots \ldots$

LESSON 3--PLANT GROWTH CYCLE $\ldots \ldots \ldots \ldots \ldots \ldots$

\section{SCALE AND STRUCTURE}

LESSON 4--CIRCULATORY SYSTEM (HEMOPOIETIC) $\ldots \ldots \ldots \ldots \ldots 13$ LESSON 5--NERVOUS SYSTEM $\ldots \ldots \ldots \ldots \ldots \ldots \ldots \ldots \ldots$

\section{SYSTEMS INTERACTION}

LESSON 6--NUTRITION FOR HEALTH $\ldots \ldots \ldots \ldots \ldots \ldots \ldots \ldots \ldots$

LESSON 7--NUTRITION AND RELATED DISEASES $\ldots \ldots \ldots \ldots \ldots 24$

\section{ENVIRONMENT - ECOSYSTEMS}

Environmental Awareness

LESSON 8--CHEMICAL CONTAMINANTS AND LIFE $\ldots \ldots \ldots \ldots \ldots 28$

LESSON 9 --NATURE'S HABITATS $\ldots \ldots \ldots \ldots \ldots \ldots \ldots \ldots \ldots \ldots \ldots$

LESSON 10--YOU AND YOUR ENVIRONMENT $\ldots \ldots \ldots \ldots \ldots \ldots$

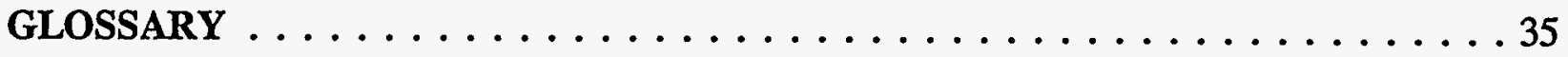

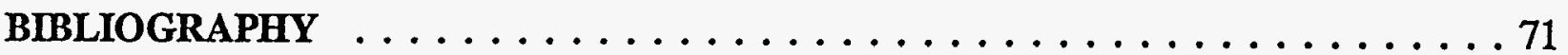





\section{OBSERVATION}




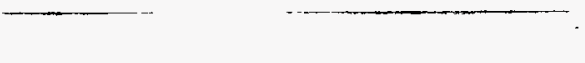




\section{OBJECTIVES:}

To increase observational skills, and analyze chemical changes and the affects of chemicals on the habitat.

\section{MATERIALS:}

Small glass containers (baby food jars, food jars, beakers, flasks) copper pennies, copper nitrate, copper sulfate, silver nitrate solution (drugstore), sodium chloride (table salt), tap water, distilled water, mercury nitrate, ammonium chloride, sulfuric acid, hydrochloric, white vinegar, chalk, plastic funnel, filter paper as coffee filter, sugar, sand, blue and yellow food dye, water, cooking oil, rubbing alcohol (isopropyl), plastic spoons.

Chemicals used everyday:

Hot plate, small sauce pan, measuring cup and spoons, lemon juice, white vinegar, carbonated $\mathrm{H}_{2} \mathrm{O}$, soap solution, red cabbage leaves, red onion, alka seltzer, bromothymol blue, indicator (pet soln.) phenol red, salt, sugar, litmus or pHydrion paper, glasses, aluminum foil, spoons, ammonia, lime $\left(\mathrm{CaOH}_{2}\right)$, magnesia, rolaids, baking soda, muriatic acid ( $\mathrm{HCl})$.

\section{BACKGROUND INFORMATION:}

The child will learn the good and the bad effects of chemical reactions and interactions. Chemicals are important ingredients in living processes but in certain concentrations and combinations, they can be harmful to your health. The children will observe the natural interactions of some common inorganic and organic chemicals. They will explore the properties and uses of some of these chemicals.

\section{SCIENTIFIC PROCESS:}

There are certain chemicals that are called minerals that are essential for good health. Some chemicals are important in the production and preparation of food, hygiene as medication, cleaning agents, etc. These are acids which react with bases to give neutral solutions. Other chemical reactions can release dangerous vapors or gases. Still others are used to act upon compounds in producing food, as cleansing agents, or stimulants and growth factors in plant and animal development.

\section{PROCEDURES:}

A) Demonstration of gas production.

1) Mix vinegar and chalk. Observe bubbles [releases gas $\left.\left(\mathrm{CO}_{2}\right)\right]$.

2) Mix ammonia plus muriatic acid (do not breath vapor). Perform this experiment outside or with good ventilation.

3) Mix baking soda and muriatic acid. Observe reaction and feel outside of container.

4) Mix Alka Seltzer and water. With each of these reactions have the child feel the container--hot or cold--and record results.

B) Demonstrate precipitation reactions. The child will mix equal amounts of each chemical--2 tablespoons.

1) Mix silver nitrate with sodium $\mathrm{NACl}$ (Sodium Chloride) or $\mathrm{NH}_{4} \mathrm{Cl}$ (Ammonium Chloride). Record results. 


\section{CHEMICAL CHANGES (continued)}

Lesson 1

2) Mix lead nitrate with sodium chloride, ammonium chloride, or potassium chloride [salt substitute]. Record results.

3) Mix tap water with sodium ammonium or potassium chloride. Record results. -

4) Mix a) copper sulfate and ammonium chloride; b) copper nitrate and ammonia chloride. Record results.

In these experiments the children should observe white or bluish white "powder" settling in bottom of container.

C) Reactions with bases.

1) Mix household bleach in $1 / 2$ cup of $\mathrm{H}_{2} \mathrm{O}$ and feel the container.

2) Mix baking soda with a cup of water and have children feel the outside container.

a) Separate the baking soda mixture into 2 containers (A \& B).

1) To container $A$ add silver nitrate. 2) To the container B check the $\mathrm{pH}$ with litmus paper or pHydrion paper, then add lemon juice to this solution B.

Check the $\mathrm{pH}$ of this new solution and that of the lemon juice.
3) Compare the $\mathrm{pH}$ of grapefruit to that of an apple using litmus or pHydrion paper.

D) Investigate common household chemicals; acids and base compounds are all around you.

1) Test the following foods with litmus paper; oranges, turnips tomato juice, lemon juice, apples, apricots, plums, bananas, bleach, vinegar, oven cleaner.

2) Make solutions of the following and test the resulting solution with litmus paper.
a) baking soda
b) Alka Seltzer
c) Drano (teacher demonstrates)
d) Pepto Bismol
e) Milk of Magnesia
f) dish washing soap-liquid
g) sodium chloride

E) Some reactions illustrating neutralization:

1) In making an indicator solution: a) boil red cabbage leaves or red onion in a sauce pan and pour off the colored $\mathrm{H}_{2} \mathrm{O}$;

b) make a solution of muriatic acid $(\mathrm{HCl})$ in one container and a solution of ammonia in another container by adding one tablespoon of $\mathrm{HCl}$ and one tablespoon of ammonia to a 
$1 / 2$ cup of $\mathrm{H}_{2} \mathrm{O}$ respectively. To the $\mathrm{HCl}$ solution add a tablespoon of the indicator solution (cabbage or onion liquid).

Mix the ammonia with the $\mathrm{HCl}$ by slowly pouring the ammonia into the hydrochloric acid/indicator solution. When the solution just turns colors stop adding the ammonia. The acid has been neutralized by the ammonia.

c) The children or parent can back titrate the neutralized solution to return it to an acidic solution by adding $\mathrm{HCl}$ to the solution. The solution will turn red again.

2) Make a solution of lemon juice (measure the volume) and add a tablespoon of the indicator solution.

a) With a dropper add either a solution made of baking soda, Alka Seltzer, and/or Milk of Magnesia.

Count the number of drops it takes to neutralize the lemon

juice with one or all three of these anti-acid chemicals.

\section{VOCABULARY:}

ammonia

ammonium chloride

aluminum foil (AL) back titrate baking soda $\left(\mathrm{NAHCO}_{3}\right)$ bleach (Clorox or carbonated water Purex) chalk $\left(\mathrm{CaCO}_{3}\right) \quad$ cupric (copper) nitrate cupric sulfate hydrochloric acid indicator isopropyl alcohol (rubbing)

litmus magnesia (milk of) minerals $\mathrm{pH}$ pHydrion paper precipitation reaction (chemical) sodium chloride sulfuric acid vinegar filter paper muriatic acid ingredient lead nitrate lime $(\mathrm{CaO})$ lye $(\mathrm{KOH}$ or $\mathrm{NAOH}$ mercuric nitrate muriatic acid ( $\mathrm{HCl})$ phenol red potassium chloride properties silver nitrate stimulants titrate volume 


\section{EXTENSION ACTIVITIES:}

Students listen for news reports of chemical spills that endangers human, animal and plant life.

Investigate with parents the foods that they eat and household items they use to determine properties (acid, base, neutral)-- dangerous and harmful levels.

\section{LESSON HIGHLIGHTS}

Goal: To learn about safe and unsafe conditions for chemical combinations.

Location: Indoors.

Subject Integration: Science, Physical.

Theme: Scale and structure, Language Arts.

Time: 100 minutes.

Vocabulary: In lesson.

Environment: Created. 


\section{PREFACE FOR PLANT EXPERIMENTS}

In Lessons 2, 3 and 8, the child will observe: the germination process of covered and naked seed; the growth cycle of plants; the growth patterns and needs of plants; and the effects of various pollutants on plants. These various activities will be separated into different components and rely on the students' being responsible for the care, maintenance, and collection of data on an ongoing basis.

The child will learn more about the parts of plants from the seed to leaves and parts of flowers.

In Lesson 2 the child will learn about geotropism and germination time for plants. They will be introduced to monocotyledon (single leaf) and dicotyledon (two leave), gymnosperm (naked seeds) and angiosperm (flowering plants).

In Lesson 3 the child will study the growth rate, the affects of different wave lengths of visible light and phototropism.

In Lesson 8 the child will investigate the affects of chemicals and waste products on plant life. 
. 


\section{OBJECTIVE:}

Children will grow plants from seeds using different environments. Children will learn about growth rate and environmental needs of plants.

\section{MATERIALS:}

See through containers - 2 liter soft drink bottles, plastic cups, shallow plastic dishes (as margarine tubs, petri dishes), potting soil or dirt, sand, sawdust or straw (hay); various types of seeds--vegetable, nuts, pine, flower. Organic fertilizer as fish emulsion, ammonia nitrate granules. Tap water, filtered $\mathrm{H}_{2} \mathrm{O}, \mathrm{NaCl}$, selenium, anti-freeze, motor oil, hair spray, spray deodorant, Pam, insect spray, detergent, urea crystals.

\section{BACKGROUND INFORMATION:}

The child have learned one aspect about plants and that is that they are living things and are major part of the food chain. In this specific lesson, the child will learn about seed germination outside and within soil. The students will germinate various types of seeds and observe the direction of growth for the stems and the roots. They will also learn about the two types of seed plants, the flowering (covered and the nonflowering (naked).

The child is to maintain daily logs of the termination processes of the various seed containers.

\section{SCIENTIFIC PROCESS:}

The child will learn more about hypertonic versus soil germinated seeds. They will become knowledgeable in the geotropism response of plant development. They will also learn the anatomical differences between monocotyledons and dicotyledon seed plants.

PROCEDURES: ACTIVITY 1

Various types of seeds can be used however the best are beans (lima, kidney, green beans, pole beans, pink, blackeye). To demonstrate geotropism and dicotyledon structure, lima beans are best.

A) Use a clean cup or glass; place paper towels or blotting paper around the inside edge of the container. Place the seeds in different directions: up, down, sideways, and between the glass and paper. Add water and keep paper moist by maintaining $\mathrm{H}_{2} \mathrm{O}$ in the bottom of the container. Child should periodically observe the germination of the seeds. The child should record (5 - 7 days) the length of time it takes for seeds to completely germinate and in what directions the root and leaves grow.

After germination the plants are placed in clean soil and used in other experiments, or planted in the garden.

B) Children can take and soak the lima beans or other large size beans overnight.

The next day the child can remove the outer covering and examine the inner side of the seed. They should see the embryo of the plant which will consist of the young leaves or leaf, the root section, and the fuel supply for the germination of the seed. 
C) The child should prepare three containers with clean soil and plant similar seeds as in $\mathrm{A}$ in the soil. The planted seed should be kept moist, and can be covered with cellophane to speed up germination. The child should compare the germination times for seeds in the soil and those on moist towels.

All plants should be grown for at least four months in order to conduct the other activities with these developing plants.

\section{VOCABULARY:}

ammonia nitrate

angiosperms

detergent

embryo

geotropism

monocotyledons

pollutants

sodium chloride

urea

\section{EXTENSION ACTIVITY:}

Children and parents compare the use and non-use of fertilizer, the use of various seeds, and varying the light cycle.

\section{LESSON HIGHLIGHTS}

Goal: Children will learn the life cycle of plants and their growth patterns.

Location: Indoors and outdoors.

Theme: Scale and Structure

Subject Integration: Science, Art Concepts.

Time: 2 to 4 months--50 minute segments

Vocabulary: Attached

Environment: Prepared. 
Germination

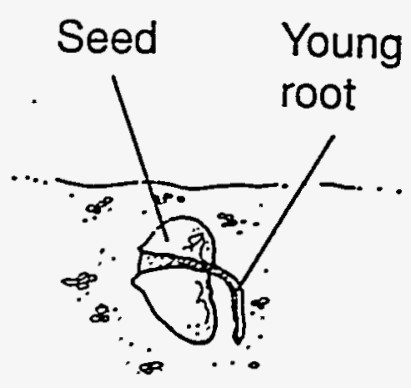

a Day 4

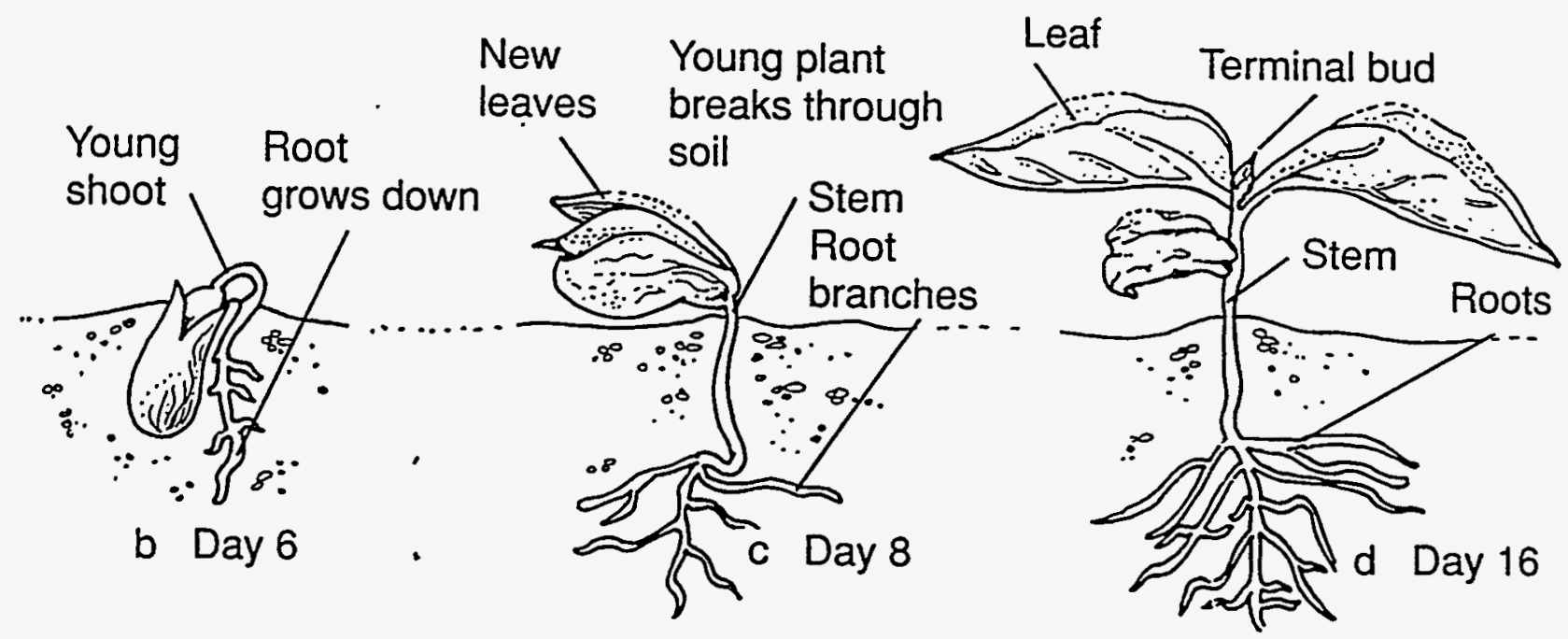




\section{OBJECTIVE:}

To demonstrate to the child the effects of different wavelengths of light and to introduce them to the effects that the depletion of the ozone layer will have on plants and animals.

\section{MATERIALS:}

Plants from Lesson 5, potting soil, plastic containers for growing plants, small rocks, wood chips, sawdust or straw, various plant seeds, colored cellophane paper or glass representing the colors of visible light and short wave length U.V. light.

\section{BACKGROUND INFORMATION:}

The growth rate of plants depends on the amount and type of light that they receive. Cellophane or glass that represents the wavelength of visible light (humans) are used to illustrate the effects of the different wavelengths of light. (Violet, blue, green, yellow, orange, red, and fair red).

Exposure of non-germinated and germinated plants will illustrate the importance of a clean atmosphere. The use of U.V. light should demonstrate the effects of excess ultraviolet light on plants. This segment, is to demonstrate what is and will occur with U.V. light, the continued depletion of the ozone layer.

\section{SCIENTIFIC PROCESS:}

The amount of light reaching a plant affects its life cycle. Certain plants grow best during specific seasons or months of the year. The light cycle plays a major role in the growth patterns of plants. The visible spectrum of light also influences the growth patterns of plants. Plants have color pigment receptor sites. One specific pigment called phytochrome controls seed germination. The stimulation of phytochrome by red light triggers the germination process. The different wavelengths of light have various affects on the growth of plants. The child will observe and record the affects of the light spectrum on plant growth.

\section{PROCEDURE:}

A. The parent will assign a particular wavelength of light to his/her child.

B. They germinated seeds in an earlier lesson. They are to take two of these plants to use in this activity. The child will place the wavelength of light assigned by the parent and position it above one of these plants. The other plant will receive unfiltered light. The child will maintain these two plants for another 2-4 weeks.

Plant three sets of seeds in soil and water these containers. On the second day the child is to place his/her wavelength of light over one of these containers and place all the containers in direct sunlight. $\mathrm{He} / \mathrm{she}$ should observe the plants on a daily basis and make certain that the moisture content of the soil is maintained. The child will maintain these containers for 6-8 weeks. 


\section{LESSON HIGHLIGHTS}

Goal: Demonstrate process and requirements for photosynthesis.

Location: Indoors and outdoors.

Theme: Observations: Scale and structure.

Subject Integration: Science, Language, Arts, Concepts.

Vocabulary: Attached.

Environment: Prepared. 

SCALE AND STRUCTURE 



\section{CIRCULATORY SYSTEM (HEMOPOIETIC) LESSOn 4}

OBJECTIVE:

Children learn the Circulatory System, importance of exercise and selected diseases of the Circulatory System.

\section{MATERIALS:}

Flip chart on Circulatory System, miniature model of heart and coronary arteries. Photographs and worksheets of the Circulatory System.

\section{BACKGROUND INFORMATION:}

The Circulatory System is one of eleven organ systems of the human body (Digestive, Nervous, Lymphatic, Skeletal, Muscular, Nervous, Endocrine, Digestive, Respiratory, Lymphatic, Urinary, and Reproductive). The Circulatory System carries oxygen and nutrients to the cells, and waste and $\mathrm{CO}_{2}$ away from the cells. The systems includes the heart, arteries and veins. It basically is a muscular system that moves blood and plasma through the body. This muscle, heart, requires regular exercise in order to maintain a healthy body. Dysfunction of this system affects the health of the body.

\section{SCIENTIFIC PROCESS:}

Individuals should have some understanding of how certain organ systems function within their bodies. The Circulatory System is very important in maintaining the body's individual cells. The cardium (heart) plays a vital role in the movement of nutrients to the cells and waste materials along with compounds synthesized in one organ and used by other tissues from these cells. The cardium connects to the cells of the body via an intricate pathway of arteries and capillaries going to the cells and veins going from the cells back to the heart. Students and their parents should learn about the arteriole and venous system, especially the heart. The children are to be taught the four chambers of the heart, and the blood vessels that enter and exit the heart. They are to be taught the names of the arteries where they can monitor their heart rate via the pulse. They will also receive reenforcement of exercise and sound nutritional requirements for a healthy Circulatory System.

\section{PROCEDURES:}

A) Children will discuss their understanding of the various parts and inter-relationships of these parts of the Circulatory System.

B) Children will label a worksheet of the Circulatory System following a diagram posted by the parent.

E) The child will learn the importance of cardiac exercise in reducing the risk of diseases of the Circulatory System. They will take their pulse at the carotid artery after sitting, after walking briskly around the room or yard, and after running a short distance. They will also take their respiratory rates after each of these activities. 


\section{CIRCULATORY SYSTEM (HEMOPOIETIC) Lesson 4}

F) Parent and child will take their pulses at the neck (carotid artery), the wrist (ulnar artery) the leg (posterior tibial artery), the temple (superficial temporal).

G) Pathologies associated with the Circulatory System:

1) Carotid artery leads to stroke or cerebrovascular infarction.

2) Coronary artery leads to heart attack or myocardial infarction.

3) Pulmonary artery leads to cell and brain dysfunction.

4) Cerebral capillaries causes hemorrhaging (or aneurysms) in brain which in turn causes a type of stroke.

5) Hypertension can also cause kidney failure due to destruction of capillaries in this organ.

These diseased conditions are related back to diet, exercise and lifestyles.

\section{VOCABULARY:}

pulmonary

systemic circulation

ventricles

atrium (auricles)

cardium

pulmonary artery

aorta

pulmonary veins

tricuspid

mitral valves

superior vena cava inferior vena cava

coronary arteries

carotid arteries

ulnar artery

dorsal pedis

\section{EXTENSION ACTIVITIES:}

A) Children should develop a family tree showing the members of their extended family who have had Circulatory System problems (highblood pressure, stroke, heart attack, pulmonary disorders, etc.)

B) Children and parents should explore the nutritional values of their foods as to complex carbohydrate and lipid content. 


\section{CIRCULATORY SYSTEM (HEMOPOIETIC) LEsSOn 4}

\section{LESSON HIGHLIGHTS}

Goal: To obtain more insight into the anatomy and physiology of the Circulatory System.

Location: Indoors.

Subject Integration: Health.

Theme: Scale and Structure.

Vocabulary: In text.

Environment: Natural and Built. 


\section{CIRCULATORY SYSTEM (HEMOPOIETIC) LESSOn 4}

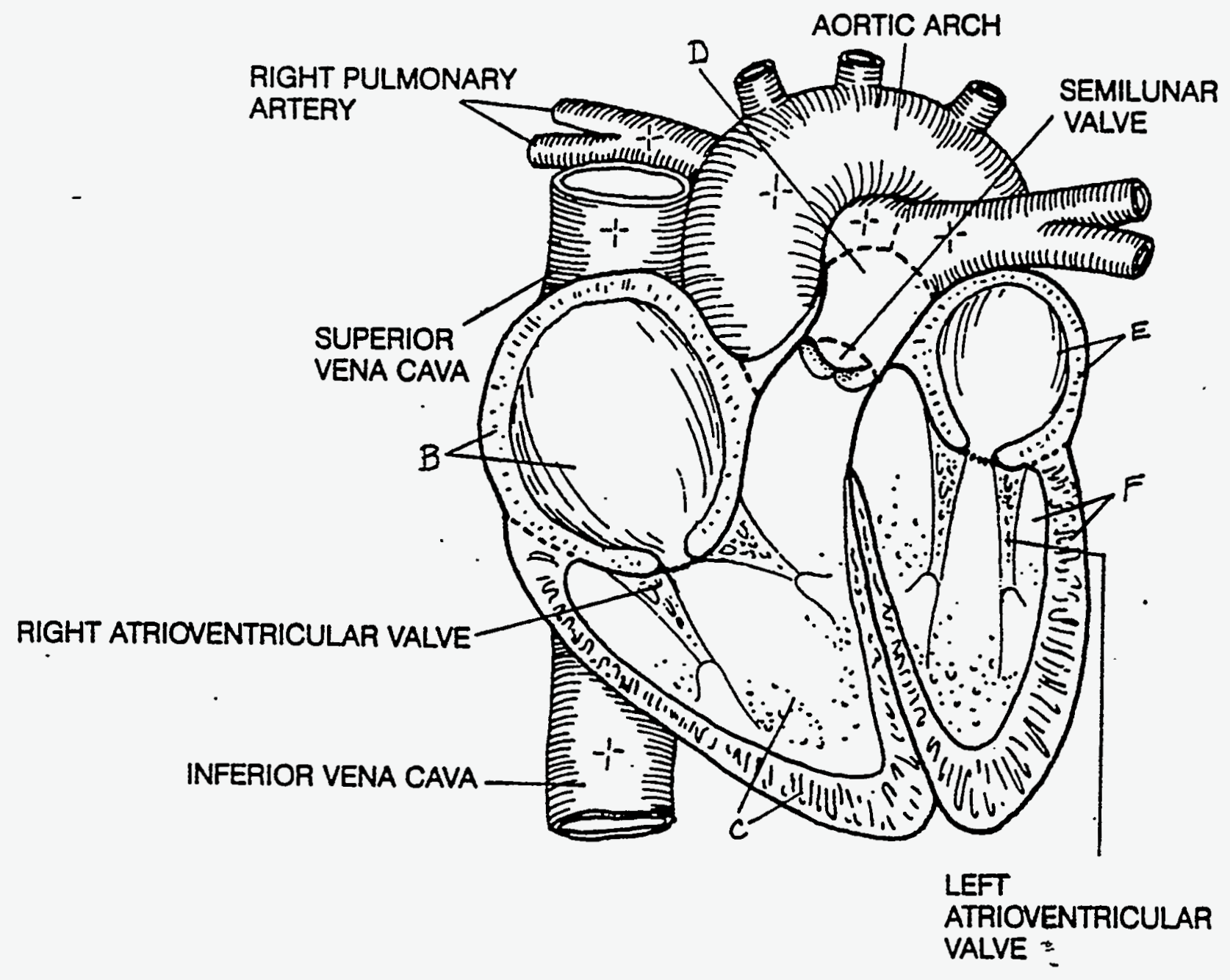




\section{OBJECTIVE:}

To learn the structure function and location of the Nervous System.

\section{MATERIALS:}

Flip chart of the nervous system; worksheets of the spinal column and head; worksheets of the nervous system, of the brain the cranial nerves, spinal cord and nerve impulse; frog, chicken or crayfish for the hearty instructor or video of the nervous system or skeleton.

\section{BACKGROUND INFORMATION:}

The Nervous System is of such importance to the functioning of vertebrate organisms that it is "housed" in a protective bony structure - a skeletal system. The Nervous System consists of the Central Nervous System (CNS) and the Peripheral Nervous System (PNS). The most fragile part of the Nervous System is protected by the cranium and spinal canal of the human Skeletal System.

The students should have learned about the Skeletal System in kindergarten, the first, and second grades. In the second grade they learned of the protective function of the Skeletal System.

The Nervous System functions to integrate, regulate and control the body or the organism. It transmits and receives message impulses to bring about motor and autonomic responses to external and internal stimuli.

\section{SCIENTIFIC PROCESS:}

The Nervous System consist of the Central and the Peripheral Nervous Systems. The Central Nervous Systems (the CNS) is comprised of the brain (cerebrum), Peripheral Nervous System which is comprised of the sensory and the motor

nerve fibers; and finally the nerve fibers are connected to the tissues and organs of the body.

The brain has 12 cranial nerves emerging from it. These nerves include, olfactory, optic, oculomotor, acoustic, glossopharyngeal and vagus. These nerves control some of the various structures that the students have learned or been exposed to in this bilingual science curriculum. The spinal cord contains 31 nerves: 8 cervical, 12 thoracic, 5 tumbar and 6 in the sacral coccygeal regions of the spinal column. These 3 nerve regions connect the trunk and limbs to the CNS. Nerves extending into the trunk (body) and limbs make up the Peripheral Nervous Systems. Heat and cold pain detected by the hands, feet, arms or legs are "picked up" by the peripheral nerves in the stimuli area transmitted to the brain via the spinal nerve system. The brain records and transmits a motor nerve response to the peripheral cells, organ or tissue and a reflex action sets in.

\section{PROCEDURE:}

A) The parent discusses and points out the location of the Nervous System in relationship to the skeleton on a chart or diagram. 
B) The parent demonstrates stimuli reflex response by a number of means such as: knee jerk reflex, cold response, response to heat, batting/blinking of eye, and others that are not dangerous.

\section{VOCABULARY:}

acoustic nerve cerebrum coccygeal cranial nerves lumbar nerves motor nerve fiber oculomotor nerve optic nerve reflex action sacral Skeletal System thoracic nerve vertebrate

\author{
Central Nervous \\ System \\ cervical nerves \\ cranium \\ glossopharyngeal \\ nerve-filter \\ nervous system \\ olfactory nerve \\ Peripheral Nervous \\ System \\ sensorynerve \\ spinal canal \\ vagus nerves
}

\section{LESSON HIGHLIGHTS}

Goal: Integrate other lower grade activities to importance and function of the Nervous System in regulations and control.

Group size: Class and groups of four.

Location: Indoors.

Theme: Scale and Structure/Health.

Subject Integration: Science, Concepts, Language Art.

Time: 100 minutes.

Vocabulary: In lesson.

Environment: Personal and Built. 
Lesson 5

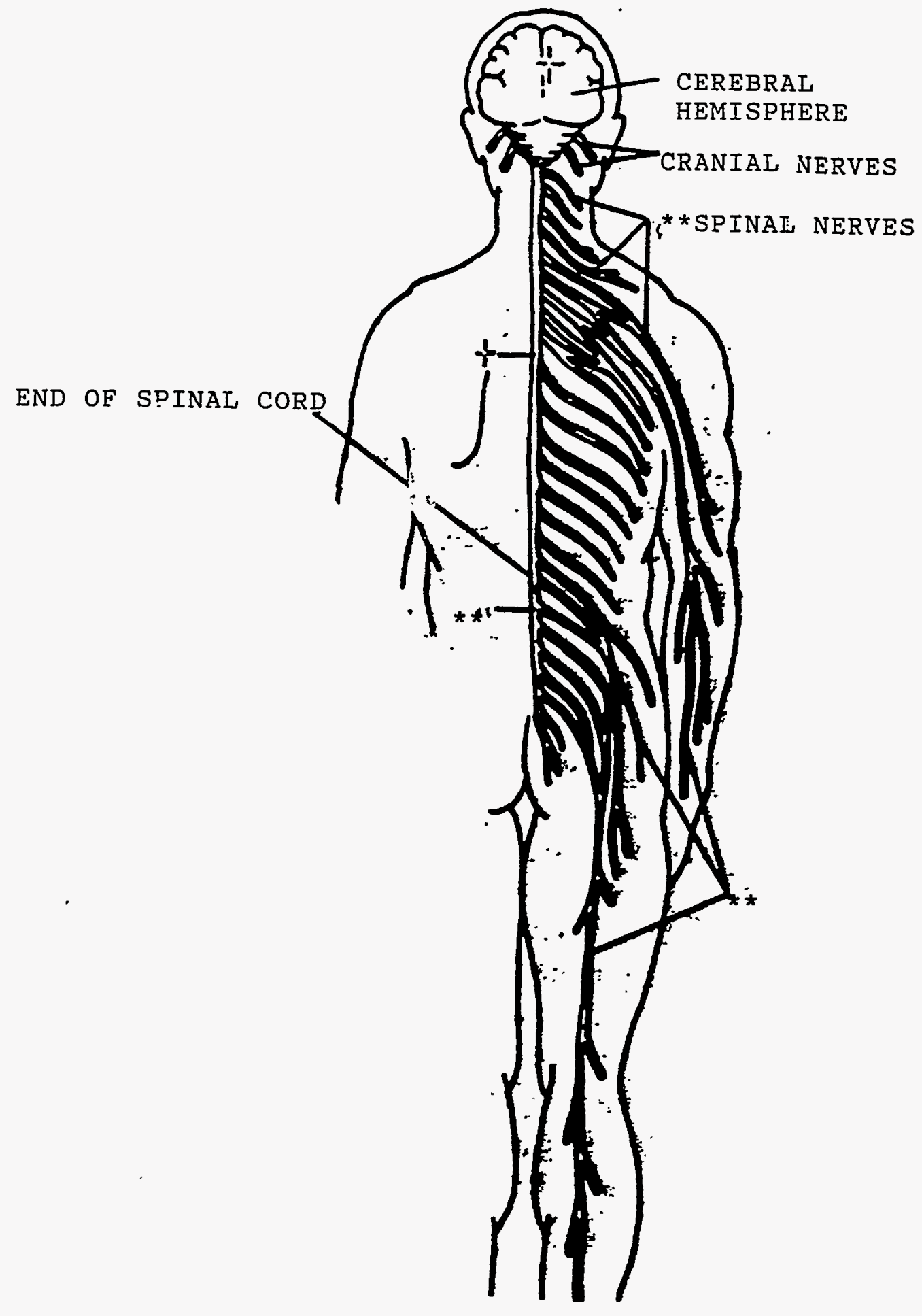




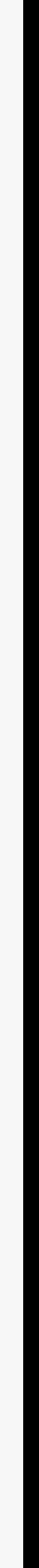




\section{SYSTEMS INTERACTION}





\section{OBJECTIVE:}

Students will be introduced to the needs of the four food groups for specific functions in their bodies.

\section{MATERIALS:}

Videotape on flow of energy, food chains and cellular metabolism; individual tables of USDA Pyramid of Foods; vitamin and mineral and flip charts; selected foods with nutritional values; worksheets with names of healthy foods; and blank worksheets for entering students selection of their favorite foods. (This information can be obtain from the library.)

\section{BACKGROUND INFORMATION:}

In earlier grade level activities the children were introduced to some aspects of nutrition. The activities in this lesson expand on their prior exposure to nutrition and health. The children will examine their current eating habits; compare their dietary habits to the current norms; and investigate the nutritional content of their favorite foods or meal. They will also learn the importance of an adequate intake of vitamins and minerals; the diseases that are associated with excessive food intake, and effects of foods that are low in calories content.

\section{PROCEDURE:}

A) The students will preview a video on one of the following: energy flow, food chain or cellular metabolism (ITTV).

B) The child will be issued the following materials: the Pyramid Food chart, the mini-version of nutritional food values, and blank worksheets.
C) The parent will lead the discussion on why they should eat foods from certain food groups. A review of the water soluble vitamins that are essential for generating energy and those that are important in bodily functioning shall also be reviewed.

D) The child will make a list of their favorite foods and a list of the foods for their favorite breakfast, lunch, and dinner.

a) The child will then place his/her listed foods into the four major categories of foods. These lists should be broken into five groups: 1) favorite foods 2) favorite meal at: a) breakfast, b) lunch, c) and dinner.

b) The child will analyze his/her favorite meals for containing: 1) representative foods from all food groups, 2) nutrient value of selected foods, 3) and healthiness of their diet.

E) The vitamin and mineral content of his/her meals/foods should be listed.

\section{VOCABULARY:}

dietary cellular metabolism

energy food chain

health minerals

nutrition vitamins water soluble 


\section{LESSON HIGHLIGHTS}

Goal: Learn nutritional value of foods.

Location: Indoors.

Theme: Science, Health.

Subject Integration: Science, Concepts, Art.

Time: 90 minutes.

Vocabulary: Attached.

Environment: Personal, built. 


\section{NUTRITION FOR HEALTH (continued) Lesson 6}

The Food Guide Pyramid

A Guide to Daily Food Choices

Fats, Oils, \& Sweets

USE SPARINGLY

\section{Key}

- Fat (naturally occurring and added)

- Sugars (added)

These symbols show fat and added sugars in foods. They come mostly from the fats. oils, and sweets group. But foods in other groups-such as cheese or ice cream from the milk group or french fries from the vegetable group-can also provide fat and added sugars.

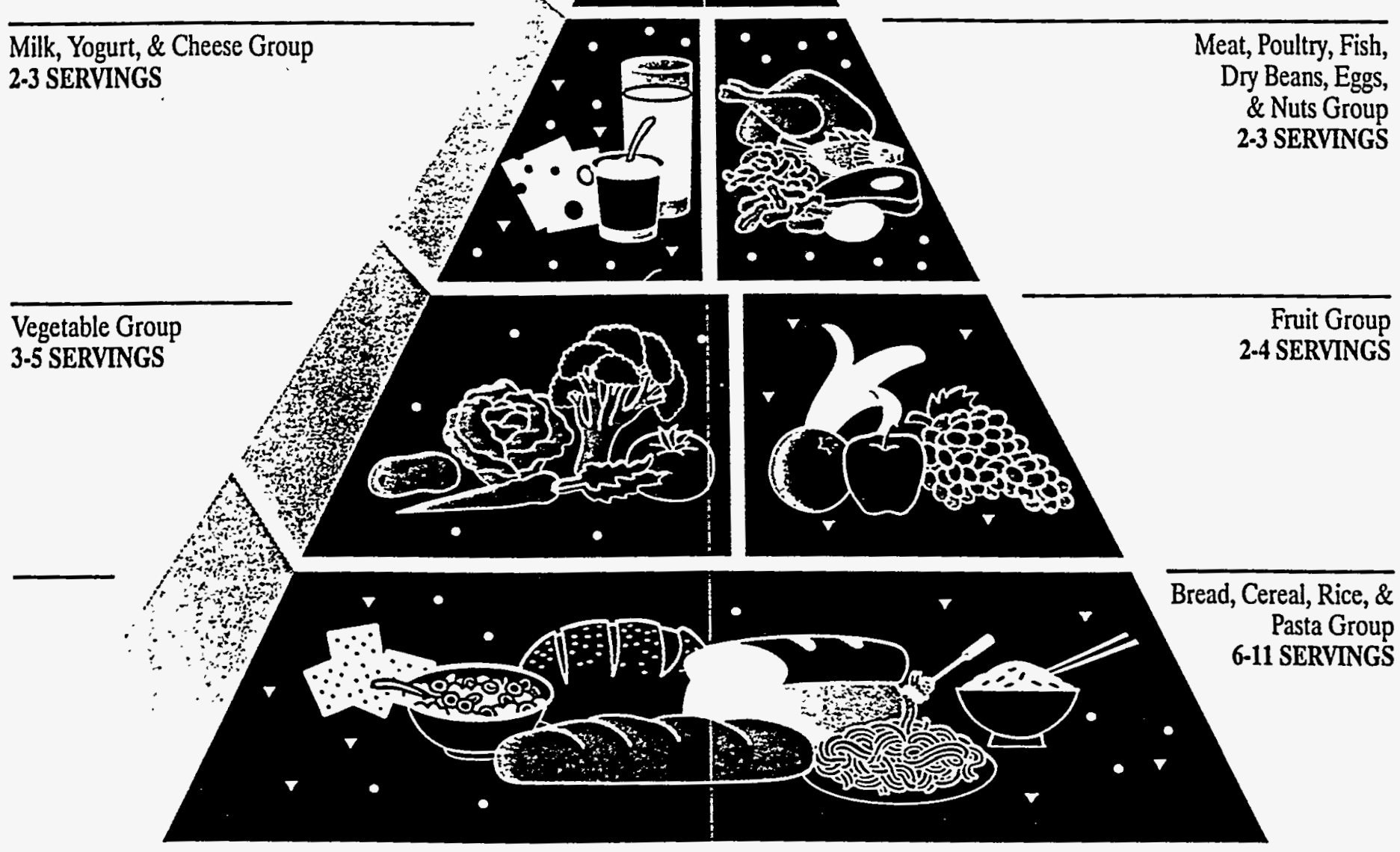

\section{Looking at the Pieces of the Pyramid}

The Food Guide Pyramid emphasizes foods from the five major food groups shown in the three lower sections of the Pyramid. Each of these food groups provides some, but not all, of the nutrients you need. Foods in one group can't replace those in another. No one of these major food groups is more important than another-for good health, you need them all. 
OBJECTIVE:

Children will learn the significance of including and reducing, or eliminating certain foods in striving for a healthy diet.

\section{MATERIALS:}

Flip charts on diseased organs: Occluded arteries, circulatory disease, lung disease. Cancer Flip Chart on colon-rectal cancer and prostrate cancer. Flip chart on "Teach Better Nutrition for Cancer." Magazines with foods in them; hand-outs on contents and calories in selected foods (can be obtained from the library).

\section{BACKGROUND INFORMATION:}

The foods that we eat have been implicated in causing or increasing the risk of certain diseases. These diseases or pathologies include: certain cancers as colon and rectal, cardiovascular disorders as heart attack and hypertension, cerbrovascular diseases as stroke, kidney and liver dysfunction, and cancer of the prostate.

\section{SCIENTIFIC PROCESS:}

Dietary intake that has high concentrations of lipid compounds have been demonstrated to contribute to: the clogging of arteries, increasing the risk of and causing colon, rectal and prostate cancers. Hypertension is the result of partially blocked arteries. Hypertension leads to other pathological changes in the body. Among these are: heart attack, stroke and kidney dysfunction.

\section{PROCEDURE:}

A) The parent will review the four food groups with the child. She/he will ask the child what foods or components found in foods contribute to cancer, hypertension, stroke,
B) The parent then discusses the food groups that have been implicated to cause specific diseases. Cholesterol levels contribute to atherosclerosis which in turn results in high blood pressure. Depending on which arteries are blocked determines the organ or tissue that will become damaged--the heart, the brain, or the kidneys.

Fatty acids in high concentration in the diet for prolonged periods of time have been implicated to increase the risk of colon and rectal cancer, as well as prostate cancer.

C) The children are to make a list of the foods they routinely eat. They are to determine the fat, carbohydrate, protein and fiber content of these foods they have listed.

D) The child has now to make a list of foods that would be more healthy for them in reducing the risk of the pathologies discussed in this lesson.

\section{VOCABULARY:}

$\begin{array}{ll}\text { cancer } & \text { circulatory } \\ \text { carbohydrates } & \text { colon } \\ \text { cardiovascular } & \text { dietary } \\ \text { cerebrovascular } & \text { dysfunction } \\ \text { complex carbohydrates } & \text { heart attach } \\ \text { hypertension } & \text { fiber } \\ \text { kidney } & \text { lipid } \\ \text { occluded } & \text { pathology } \\ \text { prostate } & \text { rectal } \\ \text { reduce } & \text { risk } \\ \text { stroke } & \end{array}$


NUTRITION AND RELATED DESEASES LEsSOn 7

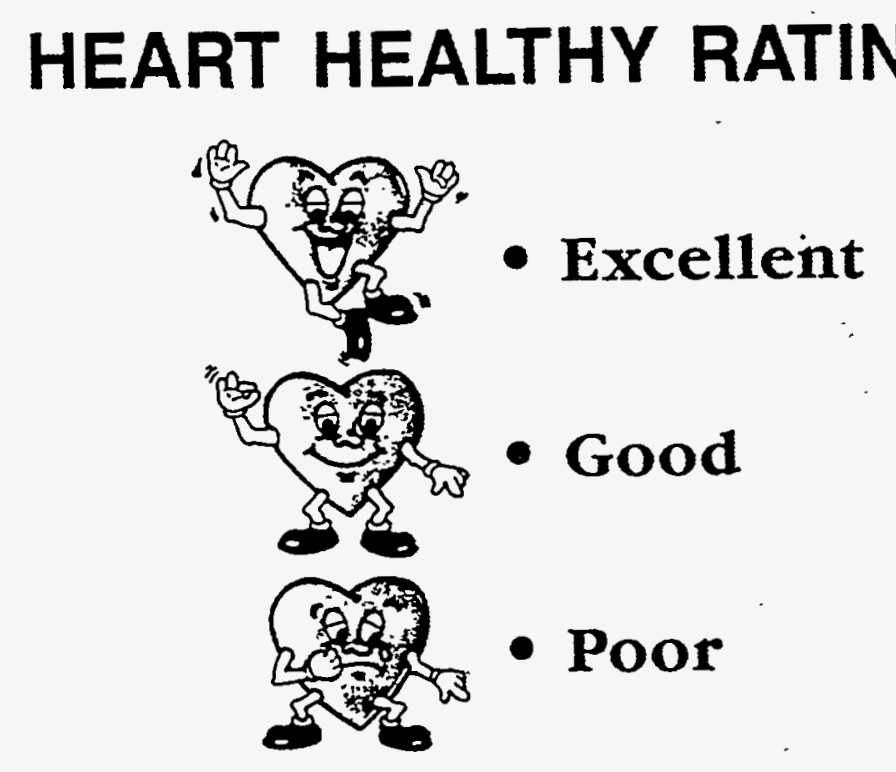




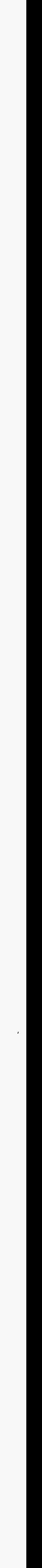




\section{ENVIRONMENT - ECOSYSTEMS}




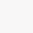




\section{OBJECTIVE:}

To demonstrate the affects of some common household, non-commercial and automotive chemicals on plant growth which can be inferred to also affect animal life.

\section{MATERIALS:}

"Drano, dish washing soap, laundry detergent, "Mr. Clean", oven cleaner, automotive oil, radiator coolant, transmission fluid, battery acid (sulfuric acid--commercial drain cleaner), liquid pool chlorine, germinating and growing plants.

\section{BACKGROUND:}

The improper discarding of hazardous waste usually results in contamination of the environment. The dumping of chemicals into the street gutters which drain into the bay, estuary, flood control systems, lakes or rivers eventually end up in animal or plant tissue. Similarly, dumping of chemicals onto the soil ultimately seeps into the water table or remains in the topsoil to be absorbed by plant roots. The end results of these acts is the contamination and polluting of the water, soil, and atmosphere, which in turn will affect animal and plant life.

\section{SCIENTIFIC PROCESS:}

Solvents and solutes can ultimately end up in the water table or in the foods that are eaten. Chemicals, either in solute or solvent or a combination of the two, can contaminate the soil; watershed washes the chemicals into the water system or the chemicals can filter into the water system. These chemicals then act as toxic agents to animal and plant life. Many of the household and automotive chemicals are harmful to domestic animals, humans and plants.

\section{PROCEDURES:}

A) The parent discusses with his/her understanding of soil and water pollution and the affects that the pollutants have on living organisms.

B) The children will use. plants previously grown, germinate and plant other plant seeds, and allow the newly growing plants to continue to grow for 3 - 4 additional weeks.

C) Child will maintain two sets of plants as controls: the previously grown hypertonic and planted seed plants (Six plants) will receive only $\mathrm{H}_{2} \mathrm{O}$ and nutrients; the experimental group will consist of one to two plants per chemical treatment.

D) If two experimental plants are used per chemical pollutant then an undiluted and a 50\% diluted solution of the chemical will be used as the source of $\mathrm{H}_{2} \mathrm{O}$.

E) They will maintain their plants for three to four weeks, making daily observations and recording the results.

One note: The plants should receive some form of nutrients as ammonia nitrate, vitamin B-1 or fish emulsion.

\section{VOCABULARY:}

$\begin{array}{ll}\text { battery acid } & \text { chemicals } \\ \text { commercial } & \begin{array}{l}\text { contamination } \\ \text { drain cleaner }\end{array} \\ \text { diluted } & \text { germinate } \\ \text { flood control } & \text { pollution } \\ \text { hypertonic } & \\ \text { water table } & \end{array}$


OBJECTIVE:

Investigate, record and analyze the natural habitats of plants and animals.

\section{MATERIALS:}

Pencils, notepads, string, various wire mesh screens (geologists, anthropologists, soil sampling screens), trowels, collection containers, fishnets.

\section{BACKGROUND INFORMATION:}

Examine the natural habitats of plants, fungi, animals (invertebrates and vertebrates), and protist organisms. The organisms that will be found in the students natural habitat will depend on the area that is investigated: seashore, lake front, wooded park, marsh area, state, city or county parks, and open range. No matter how small or how large the area examined for the presence of living organisms, you will find species in a small environment (microcosm) as well as a large environment (macrocosm). Each living organism will have its own ecological niche within the overall ecosystem. By marking off an area and subdividing it into small sections (transection), you can determine the coexistence of different plant, animal, fungi and other microscopic organisms. It does not matter the geographic location; there are ecosystems present.

\section{SCIENTIFIC PROCESS:}

The systematic examination of: 1) a designated section; 2) region; and 3) a variety of species, genus, families and classes of organisms will be conducted. These organisms may be free-living or living with, or within another organism. In the earlier grades of this activity, the students learned about organisms such as earthworms, and isopods that aided in the decomposition of decaying organic matter such as compost heap. This was a built environment. The same relationships exist in nature. In moist shady areas you can see species of mushrooms sprouting from the ground. The mushroom depends on dead or decaying matter for its existence. Mushrooms are a species that are found in a specific family of fungi. You can observe other types of fungi around and on other species of plants or animals. A closer observation of the ground or water will reveal a number of other species of living organisms present in a given section. Each of these organisms have a particular function and location within the overall community of plants, animals and other kingdoms of living organisms. This is the ecological niche of the species. Within every ecosystem, there exists a food chain. In your investigations determine what the food chain is in your microcosm.

\section{PROCEDURES:}

The parent will review the process for investigating sections of natural habitats with the child.
A) The child should do a very minimum disturbance of these environments.
B) When they turn over a rock to examine what is beneath the rock, the rock should be replaced exactly as it was.
C) The child should not pull up, displace or damage any plant life.
D) When taking soil samples, the sorting of soil should be done close to the sample area.


E) The finest layer of soil should be sifted onto a strip of clean plastic sheeting. After completing the analysis of the inhabitants and composition of the soil, the contents should be replaced and tapped down lightly.

\section{LESSON ACTIVITIES:}

\section{No. 1 Wooded area.}

a) One group will examine the various types and distribution of the plants. If the same types of plants or different types are in the 36 square feet transect area, what is the distance apart between these plants?

b) A second activity will examine a similar area but will focus on the subsoil (subterranean) organisms. They should look for organisms that inhabit the soil including seeds, fungi, etc.

c) The last activity will be tothe same area, looking for animal tracks and droppings. In this activity they will also look for signs of human pollution in the form of discarded waste/garbage.

This same procedure can be conducted at a lake front, river front, estuary, marsh area, intertide pool area, or regional, county or state parks.

\author{
VOCABULARY: \\ anthropologist \\ decaying \\ ecological niche \\ geographic \\ habitat \\ isopods \\ macrocosm \\ microscopic \\ subterranean \\ trowels
}

compost

ecosystem

food chain

geologist

invertebrate

kingdoms

microcosm

protist

transection

vertebrates

\section{EXTENSION ACTIVITY:}

The whole family can go on an ecological exploration to another area: seashore, open field (non-cultivated), etc. 


\section{LESSON HIGHLIGHTS}

Goals: Students examine a natural living habitat.

Group size: Cooperative groups of four.

Time: 120 minutes.

Vocabulary: In body of activity.

Theme: Ecology.

Subject Integration: Science, Language Arts, Cooperative Learning, Environmental Investigation.

Environment: Natural. 


\section{OBJECTIVE:}

To continue exploring the important needs of recycling and care for the environment.

\section{MATERIALS:}

Balloons, plastic ring holders from 6-pack cans, 2-liter soda bottles, half-gallon and gallon plastic milk cartons, margarine tubs, yogurt containers, plastic wrap, aluminum foil.

\section{BACKGROUND INFORMATION:}

Reducing the amount of waste that ends up in landfill areas has become a major concern of the United States and other large industrialized countries. The major concern is the preservation and restoration of the environment. This set of activities focuses on methods to reduce landfills by recycling materials, either through alternate use or establishing local collection sites for recyclable materials that can be sold to recycling centers. The activities will also illustrate some waste materials that are detrimental to wildlife. Additionally, children will explore ways to reduce nonbiodegradable waste, either via recycling or alternate packaging/manufacturing methods.

\section{SCIENTIFIC PROCESS:}

The increase in use of plastics and styrofoam made from non-biodegradable materials, coupled with metallic substances such as tin and aluminum, has increased the amount of waste material that must be disposed. Plastics and styrofoam are made from organic compounds such as polystyrene $\left(\mathrm{C}_{8} \mathrm{H}_{8}\right)_{\mathrm{N}}$, polycarbonate, polyethylene, nylon, polyesters, etc. These compounds, in these forms, were made to withstand certain external forces. Heat melts them but does not totally destroy them. Most of these plastics are not destroyed by chemicals.

These materials must be melted down to be used in other manufacturing ventures. The students will review methods of recycling these extruded or molded polyorganic compounds.

\section{PROCEDURE:}

A) Parents will lead the discussion on the importance, methods and uses of recycled plastics, aluminum, tin and other household materials that are polluting the environment.

B) Children will learn the dangers of discarded plastic from 6-pack cans. The parent will obtain the plastic rings from 6-pack cans. The child, will insert a balloon inside the opening and inflate the balloon. As the amount of air increases in the balloon, the child observes the reaction. This is what happens when a large or medium size bird, fish or other animal gets caught in these rings.

C) Plastic sandwich bags are other hazards to wildlife. The child can next inflate a balloon inside a plastic bag, or place the bag tightly over their nose and breathe out of their nose.

D) There are a number of uses for plastic milk cartons, soft drink containers, margarine tubs, etc. One use is to use them as containers for growing plants. The bottles can be used as a type of drip watering system placed at the base of plants. 


\section{YOU AND YOUR ENVIRONMENT (continued) Lesson 10}

VOCABULARY:

aluminum

container

polycarbonate

environment

polyesters

landfill

metallic

molded

non-biodegradable

plastic

polystyrene

polyethylene

recycle

styrofoam

tin

venture

\section{LESSON HIGHLIGHTS}

Goal: Examine dangers of non-biodegradable garbage.

Location: Indoors.

Subject integration: Science, Ecology, Arts, Language.

Theme: Energy.

Vocabulary: Attached.

Environment: Built. 
GLOSSARY 


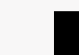




\section{GLOSARY}

\section{GLOSARIO}

$\underline{\mathbf{A}}$

Absorption: $\quad$ The act of soaking in or up.

Absorcion:

Acoustic nerve: The eighth cranial nerve, conducts stimuli to the brain.

Nervio acústico: $\quad$ El octavo nervio craneal que conduce estímulos al cerebro.

Aluminum (Al): A silvery-white bendable metallic element (chemical).

Aluminio (Al): $\quad$ Un elemento metálico blanco-plateado flexible (químico).

Aluminum foil A sheet made from the element aluminum.

(AL):

Lámina de

aluminio (AL):

Amino acids: $\quad$ Organic compound with an amino $\left(\mathrm{NH}_{2}\right)$ and carboxylic $(\mathrm{COOH})$ groups.

Aminoácidos: $\quad$ Compuesto orgánico de grupos de aminos $\left(\mathrm{NH}_{2}\right)$ y carboxilicos (COOH).

Ammonia: - A colorless, pungent gas $\left(\mathrm{NH}_{3}\right)$ found in many chemical compounds especially in fertilizer.

Amoniaco: $\quad$ Un gas íncoloro, ácido $\left(\mathrm{NH}_{3}\right)$ que se encuentra en muchos compuestos químicos especialmente en fertilizantes.

Ammonium A white crystalline compound used as an expectorant, dry cells.

Una hoja hecha del elemento aluminio.

\section{Chloride:}


Cloruro de amonio: Un compuesto blanco cristalino usado como un expectorante, células secas.

Ammonia nitrate: A colorless crystalline salt, used in fertilizers.

Nitrato de amonia: Una sal cristalina incolora, que se usa en fertilizantes.

Amphipods: $\quad$ Small crustaceans such as the beach fleas.

Anfipodo: $\quad$ Crustáceos pequeños tales como las pulgas de la playa.

Angiosperms: $\quad$ Flowering plants; seeds enclosed in an ovary.

Angiosperma: $\quad$ En plantas que florean las semillas dentro en un ovario.

Animal starch: Glycogen; composed of many units of glucose.

Almidón animal: $\quad$ Glicógeno, compuesto de muchas unidades de glucosa.

Anthropologist: A person studying origin of humans.

Antropólogo: $\quad$ El que estudia el origen de la humanidad.

Anti-freeze: $\quad$ A substance that lowers freezing point of a liquid as alcohol

Anticongelante: $\quad$ Una substancia que baja el punto de congelación de un liquido como el alcohol.

Aorta: $\quad$ Main trunk of the Circulatory System arteries carrying blood from the heart to arteries.

Aorta: $\quad$ Tronco principal del sistema circulatorio que lleva la sangre del corazón a las arterias. 
Aquatic insects: Insects that inhabit (live) in or on water.

Insectos acuáticos: Insectos que habitan (viven) en o sobre el agua.

Atrium (auricles): A chamber of the heart.

Atrio (aurícula): $\quad$ Una cámara del corazón.

Auditory bone: Bone located behind outer ear that conducts sound waves.

Hueso auditvo: $\quad$ Hueso localizado detrás del oido externo que conduce ondas sonoras.

Auditory: $\quad$ Organ or sense of hearing.

Auditivo: $\quad$ Organo o sentido de oído.

Autotroph: $\quad$ Organisms capable of manufacturing own food.

Autotrofia: $\quad$ Organismos capaces de producir su propia comida

$\underline{\mathbf{B}}$

Back titrate: Reverse titrate to double check concentration of a solution.

Titular: $\quad$ Revalorización inversa para revisar la concentración de una solución.

Bacteria: Unicellular microorganisms, free-living or parasitic.

Bacteria: $\quad$ Microorganismos unicelulares, autónomos o parásitos.

Baking soda: Sodium Bicarbonate $\left(\mathrm{NAHCO}_{3}\right)$ used in baking, as an anti-acid, etc.

Bicarbonato Bicarbonato de sodio $\left(\mathrm{NAHCO}_{3}\right)$ que se usa para cocinar, como anti-ácido, de soda: etc.

Battery acid: Diluted sulfuric acid used in device to generate electrical current via chemical reaction. 
Acido de bateria: Acido sulfúrico diluido usado en una unidad para generar corriente eléctrica, a través de una reacción química.

Bile salts: $\quad$ Liver generated steroid aids in digestion of fatty acids.

Sales biliares: $\quad$ El esteroide generado por el higado, ayuda en la digestión de acidos grasos.

Bleach (Chlorax Chemical agent used to remove color from cloth.

or Purex):

Blanqueador $\quad$ Agente químico que se usa para remover colores en telas.

(Clorax o Purex):

Brine shrimp: Small crustaceans found in highly concentrated salt water.

Camarón de agua: Crustáceos pequeños que se encuentran en aguas con alta concentración de sal.

$\underline{\mathbf{C}}$

Cancer: $\quad$ Malignant neoplasms (new growth) that invade and spread.

Cáncer: Neoplasmas malignos (crecimiento anormal) que invade $y$ se extiende por el cuerpo.

Canine: $\quad$ Member of family Canidae, includes dogs, foxes, wolves.

Canino: $\quad$ Miembro de la familia de los cánidos, incluye a perros, zorros, lobos.

Carbohydrates: Compounds that include sugars, starches and cellulose (CHOH)n.

Carbohidratos: $\quad$ Grupo de compuestos quimicos como azúcares, almidones y celulosa (CHOH)n.

Carbonated water: Water charged with carbon dioxide gas, as found in beverages.

Agua carbonatada: Agua que contiene gas de bioxido de carbono, y se encuentra en bebidas. 
Cardiovascular: Involves the heart and blood vessels.

Cardiovascular: $\quad$ Incluye el corazón y los vasos sanguíneos.

Cardium: $\quad$ The heart.

Cardio: $\quad$ El corazón.

Carnivore: $\quad$ A flesh eating organism or plant; a predatory organism.

Carnivoro: $\quad$ Un organismo que come carne o plantas; un organismo rapaz.

Carotid arteries: Two major arteries in the neck that transport blood to the head.

Arterias carótidas: $\quad$ Dos arterias importantes en el cuello que llevan sangre a la cabeza.

Cellular Breakdown of food substances into energy, water and carbon dioxide.

metabolism:

Metabolismo celular: Desdoblamiento de substancias alimenticias en energía, agua y bibxido de carbono.

Central nervous: Part of the Nervous System comprised of the brain and spinal cord.

Sistema nervioso Parte del sistema nervioso compuesto por el cerebro y médula espinal. central:

Cerebellum: $\quad$ Part of the hindbrain concerned with motor coordination.

Cerebelo: $\quad$ Parte del rombencéfalo relacionado con la coordinación del movimiento muscular.

Cerebrovascular: Blood vessels that supply the brain.

Cerebrovascular: Vasos sanguínos que abastecen el cerebro. 
Cerebrum: $\quad$ Part of the forebrain; consists of two symmetrical hemispheres (the brain). Cerebro: $\quad$ Parte del prosencéfalo; consta de dos hemisferios simétricos (el cerebro).

Cervical nerves: Nerves that branch from the neck region.

Nervios cervicales: $\quad$ Nervios que se ramimifican a partir de la región del cuello.

Chalk: $\quad$ A soft, compact cảlcium carbonate $\left(\mathrm{CaCO}_{3}\right)$ used for marking on a board.

Tizalgis: $\quad$ Un compuesto de carbonato de calcio (CaCO3) suave, usado para marcar en un tablero.

Chemicals: $\quad$ Substances that are used or produced in a chemical reaction as sodium chloride.

Productos Substancias que se emplean o producen en una reacción química como el Químicos: $\quad$ cloruro de sodio.

Chemosynthesis: Synthesis of organic substances as food nutrients using chemical energy. Síntesis química: $\quad$ Síntesis de substancias orgánicas como los nutrientes alimenticios usando energía quimica.

Cholesterol: $\quad$ A type of lipid - a sterol, synthesized by the liver.

Colesterol: $\quad$ Un tipo de lípido, un esterol, sintetizado por el hígado.

Circulatory: Internal transport system comprised of heart, blood vessels and flood.

Circulatorio: $\quad$ Sistema de transporte interno que comprende el corazón, vasos sanguíneos y su flujo.

City council: Administrative body of a city.

Consejo municipal: Cuerpo administrativo de una ciudad. 
Contaminants: $\quad$ To make impure or corrupt by contact or mixture.

Contaminantes: $\quad$ Que hacer impuro o corrupto por contacto o mezcla.

Contamination: Act of contaminating or making impure.

Contaminación: $\quad$ Acción de contaminar o hacer impuro.

Copepoda: $\quad$ Group of fresh or marine water crustaceans as daphnia.

Copépodo: $\quad$ Grupo de crustáceos de agua fresca o marina como la dafnia.

Coronary arteries: Arteries that supply blood to heart.

Arterias

coronarias: $\quad$ Arterias que llevan la sangre al corazón.

Cranial nerves: 12 pair of nerves emerging from brain.

Nervios craneanos: 12 pares de nervios que salen del cerebro.

Cranium: $\quad$ The part of skull housing brain.

Cráneo: $\quad$ La parte del cráneo que contiene el cerebro.

Cupric (copper) Chemical compound of copper and nitrate $\mathrm{CuNO}_{3}$. nitrate:

Nitrato cúprico Compuesto químico de cobre y nitrato $\mathrm{CuNO}_{3}$. (cobre): 
Coccygeal (coccyx): Four ankylosed (fused) rudimentary vertebrae at lower extremity of spinal column tail bone.

Coccígeo (cóccix): Cuatro vertebras elementales anquilosadas (juntas) en la extremidad baja del hueso de la cola de la columna vertebral.

Cochlea: Division of internal ear, spiral-shaped cavity.

Cóclea: $\quad$ División del oído interno, cavidad en forma de espiral.

Colon: $\quad$ Part of large intestine extends from the cecum to the rectum.

Cólon: $\quad$ Parte del intestino grueso que se extiende desde el ciego hasta el recto.

Commercial: $\quad$ Dealing with interchange of goods.

Comercio: $\quad$ Negociar, comprar y vender géneros.

Complex Sugars and starches that contain high amounts of fiber in the form of carbohydrates: cellulose.

Complejo de Azúcares y almidones que contienen altas cantidades de fibra en forma de carbohidratos: celulosa.

Compost: $\quad$ Mixture of decaying organic matter used as fertilizer or humus.

Abono: $\quad$ Mezcla de materia orgánica descompuesta que se usa como fertilizante 0 humus.

Consumers: $\quad$ One who eats or drinks up. A heterotrophic organism in a food chain that ingests other organisms or matter.

Consumidores: $\quad$ Quien come o bebe. Un organismo heterotrófico en una cadena cimeriaia que ingiere otros organismos o materia.

Container: $\quad$ Capable of holding something.

Recipiente: $\quad$ Capaz de contener algo. 
Cupric sulfate: Chemical compound of copper and sulfate $\mathrm{CuSO}_{3}$

Sulfato cúprico: $\quad$ Compuesto químico de cobre y sulfato $\mathrm{CuSO}_{3}$.

$\underline{\mathbf{D}}$

Decaying: $\quad$ Decomposing, rotting, deteriorate.

Deteriorar: $\quad$ Descomponer, pudrir, deteriorar.

Decibels: $\quad$ Unit to express intensity of sound waves.

Decibeles: $\quad$ Unidad que expresa la intensidad de las ondas sonoras.

Decomposers: $\quad$ The breakdown, decay, of matter via chemical or mechanical action.

Descompuestos: $\quad$ La descomposición, putrefacción de la materia por medio de la acción química o mecánica.

Detergent: Cleaning agent.

Detergente: $\quad$ Agente limpiador.

Dicotyledons: $\quad$ Flowering plant whose seeds have two leaves.

Dicotiledón: $\quad$ Planta que florece cuya semillas tienen dos hojas.

Dietary: $\quad$ Regulated amount of food system of food intake affecting health.

Dietético: $\quad$ Sistema de regulación de la cantidad de alimento ingerido que determina la salud.

Digestive enzyme: Chemical (protein) that aids in breakdown of food.

Enzima digestiva: Producto químico (proteina) que ayuda en el desdoblamiento de los alimentos. 
Digestive system: Consists of alimentary canal, liver, pancreas and gall bladder and intestines.

Sistema digestivo: Formado por el canal alimenticio, estómago, hígado, páncreas, vesícula biliar y los intestinos.

Diluted: $\quad$ To lessen strength, potency by admixture.

Diluído: $\quad$ Añadir líquido en las disoluciones para reducir la fuerza o concentración.

Dorsal pedis: Artery.

Dorso del pie: $\quad$ Arteria.

Drain cleaner: $\quad$ Material that clears cleans drains, usually a chemical.

Limpiador de tubos Substancia que limpia tubos de drenaje, usualmente es un de drenaje: $\quad$ producto químico.

Duodenum: Upper part of the sinall intestine that carries out digestion of food.

Duodeno: $\quad$ Parte superior del intestino delgado que lleva a cabo la digestión de la comida.

Disfunction: Malfunction.

Disfuncion: $\quad$ Que funciona mal.

$\underline{\mathbf{E}}$

Eardrum: Tympanic membrane.

Tímpano: $\quad$ Membrana del ofdo:

Ecosystem: $\quad$ An ecological community together with its physical environment viewed as a unit.

Ecosistema: $\quad$ Una comunidad ecologica que junto con su ambiente fisico se condidera 
una unidad.

Electrical signals: Transmission of electric current or impulse.

Señales

Transmisión de impulso o corriente eléctrica.

eléctricas:

Elodea:

Fresh water plant used in aquariums.

Elodea:

Planta de agua fresca que se usa en acuarios.

Embryo:

Early stages of development of an organism.

Embrion:

Primeras etapas de desarrollo de un organismo.

Emulsion: $\quad$ Liquid suspension; two immiscible liquids together.

Emulsion: $\quad$ Líquidos de suspension; dos líquidos inmiscibles juntos.

Endodontitis: Inflammation of the dental pulp.

Endodoncitis: $\quad$ Inflamación de la pulpa dentaria.

Energy: $\quad$ Available power; capacity to do work.

Energia: $\quad$ Fuerza disponible; capacidad para trabajar.

Entamoeba: Protozoan organism of order sarcodina, parasitic species to humans.

Entamoeba: $\quad$ Organismo protozoario del orden sarcodineo, especie de parásitos en los humanos.

Environment: Your surroundings; combination of external physical conditions that influence the growth and development of organisms.

Ambiente: $\quad$ Lo que lo rodea; combinación de condiciones externas fisicas que influyen en el crecimiento y desarrollo de organismos. 
$\underline{\mathbf{F}}$

Fatty acids: $\quad$ A large group of monobasic acids; obtained from animal tissue and is a secondary source of food energy for the cells of the body.

Acido graso: $\quad$ Un grupo de ácidos monobásicos; que se obtiene del tejido animal y es una fuente secundaria de energía alimenticia para las células del cuerpo.

Felines: $\quad$ Cat family - lions, tigers, leopards, domestic cat, etc.

Felinos: $\quad$ De la familia de los gatos; leones, tigres, leopardos, gato doméstico, etc.

Fiber: $\quad$ Slender filamentous material constituting animal and vegetal tissue.

Fibra: $\quad$ Materia delgada filamentosa que forman el tejido de animales $y$, vegetales.

Filter paper: $\quad$ Porous paper used to separate solids (solutes) from liquids (solvent).

Filtrode papel: $\quad \dot{P}$ apel poroso que se usa para separar sólidos (solutos) de liquidos (solvente).

Flood control: $\quad$ Regulate or keep in check water level so that it does not overflow.

Control fluvial: $\quad$ Regula o mantiene el nivel del agua para evitar que se desborde.

Food chain: $\quad$ Transfer of food energy from prey to predator.

Cadena Traspaso de energía alimenticia de la presa al depredador.

alimenticia:

Frequency: $\quad$ Number of times specified phenomenon (as wave motion) occurs within a specified interval.

Frecuencia: $\quad$ El número de veces o de fenómenos especificos, como el movimiento de la onda, que ocurre dentro de un intervalo específico.

Fructose: A monosaccharide, a simple sugar found in honey and fruit, a ketose. 
Fructosa:

Un monosacárido, un azúcar simple que se encuentra en la miel y fruta, una cetosa.

Fruits:

Frutas:

$\underline{\mathbf{G}}$

Galactose:

Galactosa:

Geographic:

Geografico:

Geologist:

Geólogo:

Geotropism:

Geotropismo:

Germinate:

Germinar:

Germination:

Germinación:
Ripen ovary of seed bearing-plant. An edible, usually sweet and fleshy part of the plant.

Ovario maduro de una planta fructifera. Parte comestible de una planta normalmente dulce y carnosa.

A simple sugar found in milk coupled with glucose forms lactose (milk sugar).

Un azúcar simple que se encuentra en la leche que junto con la glucosa forman la lactosa (azúcar de la leche).

Organization and structure of the earth and its materials.

Organización y estructura de la tierra y sus materiales.

One who studies origin, history and structure of earth.

Quien estudia el origen, la historia y la estructura de la tierra.

Response of organisms to gravity - downward growth of plant roots.

Respuesta de los organismos a la gravedad, crecimiento descendente de las raices de las plantas.

To sprout. To begin to grow.

Brotar, empezar a crecer.

Process of germinating.

Proceso de germinar. 
Giemsa:

Giemsa:

A type of dye used to stain (color) certain cell structures.

Un tipo de tinte usado para teñir o colorear ciertas estructuras de la célula.

Gingivalis: Inflammation of the gums.

Gingivitis: $\quad$ Inflamación de las encías.

Glossopharyngeal: Tongue and pharynx.

Glosofaringeo: Lengua y faringe.

Glucose:

Glucosa:

Glutamate:

Glutamato:

Glycerol:

Glicerina:

Grazers:

Animales de pastura:

Gymnosperms:

Gimnosperma:
A simple sugar, major source of energy for the human body.

Un azúcar simple, fuente de energía importante para el cuerpo humano.

An amino acid found in plant and animal tissue.

Un aminoácido que se encuentra en el tejido animal y de las plantas.

A syrupy, sweet clear liquid; a component of lipids, found in a number of commercial products such as soap and solvent.

Líquido incoloro, azucarado, de consistencia de jarabe, que se extrae de los cuerpos grasos y se emplea en ciertos productos comerciales como jabones y solventes.

Animals who feed on growing grasses.

Animales que se alimentan de pastos crecidos.

Naked seeds not enclosed within an ovary such as pine seeds.

Semillas desnudas que no están contenidas en un ovario, como las semillas del pino. 
$\underline{\mathbf{H}}$

Habitat: $\quad$ Area or type of environment in which an organism or population normally lives.

Hábitat: $\quad$ Area o tipo de ambiente donde un organismo o población normalmente. vive.

Health: $\quad$ Freedom from disease.

Salud: $\quad$ Libre de enfermedad.

Heart attack: Heart failure; seizure or abnormal heart functioning.

Ataque Deficiencia cardíaca; convulsión o funcionamiento anormal del corazón.

cardiaco:

Herbivore: $\quad$ Animal that feeds on plants or vegetation. Plant eating organism.

Herblvoro: $\quad$ Animal que se alimenta de plantas o vegetación. Organismo que come plantas.

Heterotroph: $\quad$ Obtain nutrients from organic substances.

Heterótrofo: $\quad$ Obtiene nutrientes de substancias orgánicas.

Hydrochloric acid: A fuming, volatile poisonous, highly acidic liquid solution of hydrogen chloride.

Acido Una solución liquida altamente ácida de cloruro de hídrogeno, es clorhidrico: volatil y venenoso.

Hypertension: High blood pressure. High arterial blood pressure.

Hipertension: $\quad$ Presión sanguínea alta, presión arterial alta.

Hypertonic: Higher osmotic pressure or concentration of two solutions.

Hipertónico: $\quad$ Presión osmótica alta o la concentración de dos soluciones. 
Ileum:

Ilion:

Indicator:

Indicador:

Inferior vena

cava:

Vena cava

inferior:

Ingredient:

Ingrediente:

Insulin:

Insulina:

Invertebrate:

Invertebrado:

Isopods:
Lowest portion of the small intestine between the jejunum and cecum.

Porción inferior del intestino delgado entre el yeyuno y el ciego.

Various substances, litmus or chemical, that indicate presence, absence or concentration of a substance or degree of reaction between two or more substances.

Varias substancias de tornasol o químicas que indican la presencia, ausencia o concentración de una substancia o grado de reacción entre dos o más substancias.

Lower large vein returns blood to right atrium of the heart.

Vena inferior grande que regresa la sangre al atrio derecho del corazón.

An element in a mixture or compound.

Un elemento en una mezcla o compuesto.

Polypeptide hormone secreted by pancreas, functions to regulate carbohydrate (sugar) uptake by cells.

Hormona polipéptida secretada por el páncreas, regula los carbohidratos (azúcares) captados por las células.

Organisms lacking a spinal column.

Organismos sin columna vertebral.

Crustaceans in the order Isopoda includes sowbugs and gribbles (marine). 
Isópodos: $\quad$ Crustáceos en el orden de isópodos como las cochinillas y las limnorias (marino).

Isopropyl alcohol: Rubbing alcohol; used in antifreeze, cosmetics, lotions.

Alcohol Alcohol para frotar; se usa en anticongelantes, cosméticos, lociones. isopropilico:

I

Jejunum: $\quad$ Mid portion of small intestine between duodenum and ileum.

Yeyuno: $\quad$ Porción media del intestino delgado en medio del duodeno y el ileón.

$\underline{\mathbf{K}}$

Kidney: $\quad$ Pair of organs that function to maintain water balance, acid-base concentration and excrete metabolic wastes as urine.

Riñon: $\quad$ Vicera doble que mantiene el equilibrio del agua, la concentración de la base ácida y excreta los residuos metabólicos en la orina.

Kingdoms: $\quad$ Animal-taxonomic division for classifying living organisms.

Reinos: $\quad$ La división taxónomica animal para clasificar los organismos vivientes.

$\underline{\mathbf{L}}$

Landfill: $\quad$ A method of rehabilitating land in which garbage and trash are buried, in low-laying ground to build it up.

Tierra Un método para la la rehabilitación de un basurero que consiste en Rehabilitada: $\quad$ enterrar basura y desperdicios bajo muchas capas de tierra.

Lead nitrate: Chemical compound made from the metal lead, nitrogen and oxygen $\mathrm{PbNO}_{3}$.

Nitrato de Compuesto químico hecho del metal de plomo, nitrógeno y oxigeno plomo: $\quad \mathrm{PbNO}_{3}$. 
Linoleic acid:

Acido

linoleico:

Lipids:

Lípidos:

Litmus:

Tornasol:

Liver:

Higado:

Longitudinal:

Longitudinal:

Lumbar nerves:

Nervios lumbares: $\quad$ Nervios que surgen de la region lumbar de la espina dorsal.

Lye (KOH or NAOH):

Lejia:

An essential polyunsaturated fatty acid in the human diet.

Un ácido graso de enlaces no saturados indispensable en la dieta del ser humano.

Numerous fats and fat-like substances as fatty acid steroids, phospholipid; important in membrane structures.

Sustancias grasas y grasas similares tales como los esteroides de ácido graso, fosfolipidos, importante en la estructura de las membranas.

A blue amorphous powder obtained from certain lichens that turn red with acid and blue with base compounds.

Un polvo azul amorfo que se obtiene de ciertos líquenes que se torna rojo al contacto con un compuesto acído, y al azúl con un compuesto básico.

Vertebrate gland that secretes bile, acts in metabolism of carbohydrates, fats, proteins, minerals and vitamins also in blood formation.

Glándula digestiva en los vertebrados que segrega la bilis, actúa en el metabolismo de carbohidratos, grasas, proteinas, minerales y vitaminas, $y$ en la fabricación de la sangre.

Length; running lengthwise.

Longitud; que corre a lo largo.

Nerves that arise from lumbar region of the spinal column.

Chemical composed of sodium or potassium hydroxide.

Producto químico compuesto de hidróxido de sodio o potasio: 
Lysine: An essential, crystalline amino acid used in nutrition studies.

Lisina: $\quad$ Un aminoácido cristalino indispensable usado en estudios de nutrición.

$\underline{\mathbf{M}}$

Macrocosm: The world; a large unit or system of organisms.

Macrocosmo: $\quad$ El mundo; una unidad grande o sistema de organismos.

Magnesia (milk of): A liquid compound of magnesium hydroxide used as an antacid.

Magnesia Un líquido compuesto de hidróxido de magnesio que se usa de (leche de): $\quad$ antiácido.

Measurement: $\quad$ To determine the dimension or quantity of objects.

Medida: $\quad$ Determina la dimensión o cantidad de objetos.

Mechanical: $\quad$ Automatic; manual labor use of physical force; pertaining to machines or tools.

Mecánico: $\quad$ Automático, trabajo manual, uso de la fuerza fisica, perteneciente a máquinas o herramientas.

Mercuric nitrate: Chemical compound consisting of bivalent metal mercury, $\mathrm{HG}^{+2}$, nitrogen and oxygen.

Nitrato de

mercurio:

Compuesto químico que consta de un metal de mercurio bivalente, $\mathrm{Hg}+2$, nitrógeno y oxígeno.

Metallic: $\quad$ Having characteristics of a metal as iron, lead.

Metálico: Que tiene características de un metal, como el hierro y el plomo.

Meter: $\quad$ A fundamental unit of length equal to 39.37 inches in the metric system.

Metro: $\quad \quad U n a$ unidad de longitud en el sistema métrico que equivale a 39.37 pulgadas. 
Methylene blue:

Metileno azul:
Organic compound used as a bacteriological stain and as an antidote for cyanide poisoning.

Metric:

Métrico:

Microcosm:

Microcosmo:

Microorganism:

Microorganismo:

Microscopic:

Microscópico:

Mitral valve:

Válvula mitral:

Mold:

Moho: 2Molde:

Compuesto orgánico que se usa como tinte bacteriologico y como antídoto contra el envenenamiento por cianuro.

A standard of measurement, base on the meter.

Conjunto de medidas que tiene como base el metro.

A diminute representative system somewhat similar to a larger system in constitution, configuration or development.

La representación diminuta de un sistema, análogo en configuarción constitución o desarrollo a un sistema mayor.

Microscopic organisms; requires magnification in order to see the organism such as bacterias.

Organismos microscópicos; se requiere de un amplificador para poder ver organismos tales como las bacterias.

Too small to be seen by the unaided eye but visible via a microscope.

$\therefore$

Demasiado pequeño para observarse solo a simple vista; pero visible por medio de un microscopio.

Heart valve between left auricle and left ventricule that regulates blood flow between these chambers.

Válvula del corazón entre la aurícula izquierda y ventrícula izquierda que regula el flujo de sangre entre estas cámaras.

Fungus that causes mold. 2 a hollow form o matrix for shaping a fluid or plastic substance.

Hongo que causa moho. Recipiente o matriz para moldear una substacia fluida o plástica. 
Monocotyledons: Plants that have a single embryonic seed leaf that appears at germination.

Monocotiledón: $\quad$ Plantas que tienen un solo cotiledón embriónico que aparece en la germinación.

Motor nerve fiber: Fiber that conducts (transfer) motor impulses to muscle cells.

Fibra del nervio $\quad$ Fibra que conduce (transfiere) impulsos motores a las células del músculo.

motor:

Muriatic acid: Hydrogen Chloride used as chemical in swimming pools.

Acido muriatico: $\quad$ Cloruro de hidrogeno que se usa como producto químico en piscinas.

$\underline{\mathbf{N}}$

Nerve: $\quad$ Any of the bundle of fibers interconnectary to Central Nervous System and organs or parts of the body - transmits sensory and motor stimuli.

Nervio: $\quad$ Los grupos de fibras que interconectan al sistema nervioso central con los órganos o las partes del cuerpo, transmite estímulos sensoriales y motrices.

Nerve fiber: $\quad$ Threadlike process that is part of a nerve; axon or dendrite.

Fibra del nervio: $\quad$ Proceso filiforme que es parte de un nervio; neuroeje o dendrita.

Nervous system: Coordinating mechanism that regulates internal body functions and responses to external stimuli.

Sistema nervioso: $\quad$ Mecanismo coordinador que regula las funciones internas del cuerpo y responde a los estímulos externos.

Nutrients: $\quad$ Nourishing ingredient in food. Provide nourishment.

Nutrientes: $\quad$ Ingrediente nutritivo en los alimentos. Proporciona valor alimenticio.

Nutrition: $\quad$ Assimilation of food for growth and maintenance of body cells, tissues.

Nutrición: $\quad$ La asimilación de los alimentos para el crecimiento y el mantenimiento de 
las células del cuerpo, tejidos.

$\underline{\mathbf{O}}$

Occluded: $\quad$ Cause to become closed; obstruct; block.

Ocluir: $\quad$ Que se cierra, obstruye, bloquea.

Oculomotor nerve: Either of the two cranial nerves that control muscles of the eyeballs.

Nervio oculomotor: Los dos nervios craneales que controlan los músculos del globo ocular.

Oleic acid: $\quad$ Oily liquid found in animal and vegetable oils. Found in olive oil.

Acido oleico: $\quad$ Líquido aceitoso que se encuentra en aceites animales y vegetales. Se encuentra en el aceite de olivo.

Olfactory nerve: Either of two bundless of nerve fibers; one on each side of the nasal cavity, that conduct chemical stimuli of smell.

Nervio olfativo: $\quad$ Los dos gruos de fibras del nervio a cada lado de la cavidad nasal, que conducen estímulos químicos de los olores.

Omnivorous: $\quad$ Eats both animal and vegetable substances.

Omnivoro: $\quad$ Que se nutre de ambas substancias, animal y vegetal.

Optic nerve: $\quad$ Two sensory nerves that connect the retina of the eyes with the brain.

Nervio óptico: $\quad$ Dos nervios sensoriales que conectan la retina de los ojos con el cerebro.

Oral cavity: The mouth.

Cavidad oral: $\quad$ La boca.

Ozone:

A form of allotrope oxygen $\mathrm{O}_{3}$ formed from exposure to ultraviolet radiation. 
Ozono: $\quad$ Variedad de oxígeno alotrópico de fórmula $\mathrm{O}_{3}$ que se forma por la $\underline{\mathbf{P}}$

Pancreas: Gland that lyes behind the stomach, secretes pancreatic juices and produces insulin.

Páncreas: $\quad$ Glándula que se encuentra detrás del estómago, elabora los jugos digestivos la insulina.

Pathology:

Patologia:

Peripheral nervous system:

Sistema nervioso periférico:

pH:

pH:

Phenol red:

Fenol rojo:

Phosphocholine: (Phosphatide)

Fosfollpido:
Scientific study of nature of diseases, its causes, processes, development, and consequences.

Estudio cientifico de la naturaleza de las enfermedades, sus causas, procesos, desarrollo y consecuencias.

Comprises the cranial, spinal nerves and the sympathetic nervous system.

Comprende el nervio craneal, nervios raquideos y el sistema nervioso simpático.

The relative acidic concentration of a solution.

La concentración ácida relativa de una solución.

A chemical that is used as an acid - base indicator.

Un compuesto químico que se usa como un indicador básico ácido.

A lipid composed of glycerol and phosphoric acid and a nitrogenbased (i.e., lecithin) found in plants and animals.

Una grasa que contiene nitrógeno ácido fosforico y una base nitrogenada (p. ej., lecitina) y se encuentra en de plantas y animales.

Photosynthesis: The process in which chlorophyll-contain cells in greem plants convert solar energy synthetize organic compounds, carbon dioxide and water 
with the simultaneous release of oxigen.

Fotosintesis: $\quad$ El proceso en las plantas verdes que tienen clorofila en que sintetizan energía solar, materia orgánica, el bióxido de carbono y agua al mismo tiempo que despide oxigeno.

Phototropism: Growth in a plant in response to a source of light.

Fototropismo: $\quad$ Crecimiento de una planta en relación a una fuente de luz.

pHydrion paper: Paper impregnated with a indicator to measure of acidity or alkalinity of a solution; more accurate than litmus paper.

Papel pHydrion: $\quad$ Papel impregnado con indicador para medir el grado de la acidez de una solución; más exacto que el papel tornasol.

Phytochrome: Pigment found in plants that causes plants to respond to light.

Fitocromo: $\quad$ Pigmento que se encuentra en las plantas, que absorbe la luz.

Plant starch: $\quad$ Polysaccharide (polycarbohydrate) made by plants.

Almidón de $\quad$ Polisacárido (policarbohidratado) que elaboran las plantas.

la planta:

Plastic: $\quad$ Pliable, capable of being shaped, material or substance made of plastic.

Plástico: $\quad$ Flexible, capaz de ser moldeado, material o substancia hecha de plástico.

Pollutants: $\quad$ See "Contaminants".

Contaminantes: $\quad$ Ver "Contaminantes".

Pollution: $\quad$ See "Contamination".

Contaminación: $\quad$ Ver "Contaminación.

Polycarbonate: Chemical compound of repeating units of carbonate, used in making 
plastics.

Policarbonato: $\quad$ Compuesto químico de unidades repetidas de carbonato, que se usa para fabricar plásticos.

Polyester:

Poliésters:

Polyethylene:

Polietileno:

Polystyrene:

Poliestireno:
A thermo-stable resin used in paint, lackers, adhesives, etc.

Es una resina termoestable que se usa en la fabricación de pinturas, barnices, adhesivos, etc.

Plastic polymer of ethylene, $-\mathrm{CH}_{2} \mathrm{CH}_{2}$, - found in containers, electrical insulation tubing and packaging.

Polímero plastico de etileno de fórmula $\mathrm{CH}_{2} \mathrm{CH}_{2}$, que se encuentra en recipientes, tubos y empaques de aislamiento eléctrico.

Clear plastic or stiff foam $\left[\begin{array}{llllll}\mathrm{CH} & \left(\mathrm{C}_{6}\right. & \left.\mathrm{H}_{5}\right) & \left.\mathrm{CH}_{2}\right]_{n} & \text { mainly used as }\end{array}\right.$ an insulator.

Plástico claro o espuma espesa de fórmula $\left[\mathrm{CH}\left(\mathrm{C}_{6} \mathrm{H}_{5}\right) \mathrm{CH}_{2}\right]_{n}$ usada principalmente como aislante.

Potassium chloride: Water soluble solid, salt substitute, used in manufacture of mineral water.

Cloruro de potasio: Sólido soluble, subtituto de la sal, que se usa en la elaboración de agua mineral.

Precipitation:

To separate a substance in solid form from a solution.

Precipitación: $\quad$ Separar un element sólido de una solución.

Producers: Organism, as plant able to make its own food from inorganic substances.

Productores: $\quad$ Es un organismo, como la planta, capáz de elaborar su propio alimento a partir de materia inorgánica.

Properties: $\quad$ An essential or distinctive atribute or quality of a chemical element as sodium. 
Propiedades: $\quad$ Un atributo indispensable o particular o calidad de un elemento químico como el sodio.

Prostate:

Próstata:

Protein:

Proteina:

Protist:

Protisto:

Protozoan:

Protozoario:

Pulmonary:

Pulmonar:
A gland that surrounds the urethra of males at the base of the bladder. Una glándula en la base de la vejiga que rodea la uretra de los varones.

Groups of nitrogen containing organic compounds made by plants and animals; required for all life processes.

Grupos de nitrógeno que contienen compuestos orgánicos elaborados por plantas y animales; necesarios para el procesos de toda vida.

Organism of the kingdom Protist not readily classified as either plants or animals, v.e., sporozoans that cause malaria.

Organismo del reino prtisto que aún no es clasificado como planta o animal tal como el esporozoario que causa malaria.

One-celled or colony of similar celled organisms.

Una célula o colonia de organismos celulares similares.

Of or pertaining to the lungs.

Relativo o perteneciente a los pulmones.

Pulmonary artery: Conveys venous blood from right ventricle of heart to the lungs.

Arteria pulmonar: Transporta la sangre venosa del ventriculo derecho del corazón a los pulmones.

Pulmonary veins: Conveys arterial blood from lungs to left atrium of heart.

Venas pulmonares: Transportan la sangre arterial de los pulmones al atrio izquierdo del corazón. 
Reaction (chemical):

Reacción

(química):

$\underline{\text { Rectal: }}$

Rectal:

Recycle:

Reciclar:

Reduce:

Reducir:

Reflex action:

Reacción por

reflejo:

Resonances:

Resonancias:

$\underline{\text { Risk: }}$

Riesgo:

Role play:

Hacer el

papel de:
Action of chemical agents upon each other given a chemical change.

Acción o cambio químico que producen unos agentes químicos sobre otros.

Relative or pertaining to, or near the rectum.

Relativo al intestino recto.

To use again, to reprocess in order to use again.

Volver a usar, reacondicionar para usar de nuevo.

Bring down to a smaller size or amount.

Disminuir el tamaño o la cantidad.

An involuntary response to a stimulus.

Una respuesta nerviosa involuntaria a un estímulo.

Prolongation of sound by reverberation.

Prolongación del sonido por reverberación.

Exposure to chance of injury; a hazard.

Exposición a la posibilidad de un daño o peligro.

Act out a character or situation.

Represantar un carácter o situación en una obra. 
Sacrum:

Sacro:

Saliva:

Saliva:

Selenium:

Selenio:

Sensory nerve: Conveys nerve impulses to the brain.

Nervio sensorial: $\quad$ Transporta impulsos nerviosos al cerebro.

Silver nitrate:

Nitrato de plata:

A laboratory reagent made from the metal silver and diluted nitric acid. Also used in manufacturing of mirrors and a to prevente blindness in newborns.

Un reactivo usado en laboratorio compuesto de metal plata y ácido nitrico diluído, también se usa en la fabricación de espejos y para prevenir la ceguera en los recién nacidos.

Skeletal system: Bones of humans and animals that support and protect body organs.

- Sistema esquelético:

Small intestine: Part of the intestine in which digestion is completed and consists of the duodenum, the jejunum and the ileum. 
Intestino delgado: $\quad$ Parte del intestino donde la digestión se completa, consta del duodeno, el yeyuno y el ilión.

Sodium chloride: Table salt; a chemical consisting of sodium and chloride used as a food preservative.

Cloruro de sodio: Sal de mesa; un compuesto químico formado por sodio y cloruro también usado como preservativo de los alimentos.

Sound waves: Wave of sound; ascillations produced by sound from one point to the next. Onda sonora: $\quad$ Oscilaciones producidas por sonidos desde uno punto de un mio a otros del mismo medio.

Spinal canal: The canal in the vertebrae through which the spinal cord and its membranes pass.

Canal espinal: $\quad$ Canal en la colunma vertebral por el cual pasa la médula espinal y su membranas.

Stimulants: $\quad$ Something that temporarily arouses physiological or organic activity.

Estimulantes: $\quad$ Algo que excita temporalmente la actividad fisiologica u orgánica.

Streptococcus Bacterium that inhabits the mouth and can cause tooth decay through action mutants: on food particles.

Estreptococo Bacteria que se encuentra en la boca y puede causar el decaimiento mutante: de los dientes por medio de la acción a partículas de alimentos.

Stroke: $\quad$ Cerebrovascular infacction; blocking of artery (carotid) leading from heart to brain causes temporary loss of brain function. Usually results in partial or total paralysis of left side of body.

Ataque al cerebro: Infarto cerebrovascular; bloqueo de una arteria (carótida) que sale del (Embolia) corazón a la cabeza causando pérdida temporal del funcionamiento del cerebro. Normalmente ocasiona una parálisis parcial o total del lado izquierdo del cuerpo. 
Styrofoam:

Icopor:

Subterranean:

Subterráneo:

Sulfuric acid:

Acido sulfúrico:

Superior vena cava:

Vena cava superior:

System:

Sistema:

Systemic circulation:

Circulación sistematica:

$\underline{T}$

Tape measure: A tool for making measurements consisting of cloth, paper or steel Cinta' de medir: $\quad$ Una herramienta de medición hecha de tela, papel o acero, marcada con
Highly corrosive liquid, $\mathrm{H}_{2} \mathrm{SO}_{4}$, used in manufacture of variety of chemicals and materials used as a commercial drain cleaner.

Líquido altamente corrosivo, de fórmula $\mathrm{H}_{2} \mathrm{SO}_{4}$ que se usa en la fabricación de varios elementos químicos y materiales usados como limpiadores comerciales de tubos de drenaje.

Returns blood from upper portion of body to heart.

Regresa la sangre de la parte superior del cuerpo al corazón.

A group of physiologically complementary organs or parts, i.e. the nervous system.

Un conjunto de órganos que intervienen en las principales funciones, $p$. ej., el sistema nervioso.

Circulation in the entire body.

La circulación regular de la sangre en el cuerpo entero. 
una escala lineal.

Thoracic nerve: Nerve arising from the thoracic region of the body.

Nervio torácico: $\quad$ Nervio que parte de la región torácica del cuerpo.

Tin: $\quad$ A malleable, silvery metallic element, used to coat other metals to prevent corrosion.

Estano: $\quad$ Un elemento metálico plateado y maleable, que se usa para cubrir otros metales para prevenir la corrosión.

Titrate:

To determine concentration of a solution by slowly adding one liquid to another in presence of a $\mathrm{pH}$ indicator.

Titular: $\quad$ Determinar la concentración de una solución añadiendo lentamente un liquido a otro en presencia de un indicador de $p H$.

Transection: To divide by cutting transversely.

Corte

transversal: $\quad$ Dividir cortando transversalmente.

Transmission: To transmit; send from one place or point to another.

Transmisión: $\quad$ Transmitir, enviar de uno punto o lugar a otro.

Transverse: $\quad$ Crosswise; lying across.

Transverso: . Se halla o extendiende atravesado de un lugar a otro.

Tricuspid: Having three points, a valve in the heart.

Tricúspide: $\quad$ Una válvula en el corazón que tiene tres puntos.

Trophic level: $\quad$ Feeding level in a food chain of an ecosystem characterized by organisms that occupy a similar functional position in the ecosystem. 
Nivel trófico: $\quad$ Nivel que ocupa un organismo en una cadena alimenticia de un ecosistema caracterizado por organismos que ocupan una posición funcional similar en el ecosistema.

Trowels:

Trulla/Llana:

Tuning forks:

Diapason:

Tympanic membrane:

Membrana del tímpano:

$\underline{\mathbf{U}}$

Ulnar artery: Artery that passes over the ulna bone of the arm.

Arteria ulnar: $\quad$ Arteria que pasa sobre el hueso ulnar del brazo.

Ultraviolet light: Light - range of radiation wavelengths form approximately (part visible violet) 4,000 angstroms to 40 angstroms border of $x$ ray region.

Luz ultravioleta: $\quad$ La longitud de las ondas de radiación (la parte visible color violeta) de aproximadamente 40 a 4,000 angstroms del borde de la región de los rayos $X$.

Urban: $\quad$ Of or pertaining of a city.

Urbano: $\quad$ Relativo o perteneciente a una ciudad.

Urea:
A flat and bladed hand tool for digging, spreading or shaping.

Una herramienta manual plana y con cuchilla para excavar, extender 0 dar forma.

Small two-pronged metal device that when struck produces a sound of a fixed pitch used as a reference.

Pequeño aparato metálico con dos puntas que cuando se golpean produce un sonido de longitud de onda determinada y es usado como referencia.

Membrane - thin, semitransparent, oval shaped membrane separating the middle ear from external ear.

Membrana delgada, semitransparente, en forma ovalada que separa el oído medio del oído externo. 
present in the blood, urine, bile.

Urea:

Substancia nitrogenada producida por los mamiferos como producto de eliminación del amoníaco, presente el la sangre, orina, bilis, etc. .

$\underline{\mathbf{V}}$

Vaqus nerves: Tenth and longest of the cranial nerves, passing through the neck and thorax into the abdomen.

Nervio vago: $\quad$ Diez de los nervios craneales más largos, que pasan a través del cuello y tórax hacia el abdomen.

Vegetable:

Plants cultivated for an edible part such as the root, stem, leaf or flower.

Vegetales/

Plantas cultivadas para obtener la parte comestible tal como la raiz, el Verduras: tallo, la hoja o la flor.

Ventricles:

Chamber on the left or right of the heart that receives blood form the atriums.

Ventrículos: $\quad$ Las cámaras en el lado izquierdo o derecho del corazón que reciben la sangre de los atrios.

Venture:

Undertaking that is dangerous, daring or of doubtful outcome.

Aventura:

Empresa desconocida o arriesgada de resultado incierto.

Vertebrate: $\quad$ Having a backbone; of the phylum chordata.

Vertebrado: $\quad$ Que tiene espina dorsal; del filum cordado.

Vibration: $\quad$ A rapid leneal motion of a solid about an equilibrium position.

Vibración: Un cuerpo sometido a un movimiento periódico alrededor de una posición central. 
Vinegar:

Vinagre:

Visible spectrum light:

Espectro de luz visible:

Vitamin K:

Vitamina $K$ :

Vitamin $\mathbf{B}_{12:}$

Vitamina $B_{12}$ :

Vitamins:

Vitaminas:

Volume:

Volumen:

$\underline{\mathbf{w}}$

Water soluble: Dissoluable in water. alcohol stage. metabolic porcesses.
Impure diluted solution of acetic acid obtained by fermentation, beyond

Producto de la fermentación acética de un líquido alcoholico.

Light that can be seen; perceived by the eye.

Luz que se puede ver, que se percibe por el ojo.

Made in human intestine via bacterial action; important in the manufacturing (syntheisis) of 5 blood clotting factors.

Elaborada en el intestino humano a través de la acción bacterial; importante en la fabricación o sintesis de los cinco factores para la coagulación de la sangre.

Complex containing the mineral cobalt produced by bacteria in the interline, found in liver. Important in the production of red blood cells.

Complejo que contiene el mineral de cobalto producido por bacterias interlineales, encontradas en el higado. Importante en la producción de las células rojas de la sangre.

Complex organic substances essential in small amounts for regulation of

Substancias de acción enzimatica impresindibles en cantidades pequeñas para el funcionamiento normal de un organismo.

The size or extent of a three-dimensional objecto or region of space. Medida tridimensional del espacio ordinario ocupado por un cuerpo. 
Soluble en

agua:

Water table:

Depth or level below which the ground is saturated with water.

Nivel hidrostático:

Determinación del nivel o profundidad de la tierra saturada con agua.

Wave length:

Distance between two points of a cyclic motion.

Longitud

de onda:

$\underline{\mathbf{Y}}$

Yard stick: $\quad$ Graduated measuring stick one yard in length.

Vara de una yarda: Tabla de medir graduada en una yarda de longitud.

$\underline{\mathbf{Z}}$

Zooplankton: Floating, microscopic aquatic animals.

Zooplancton: $\quad$ Animales microscópicos, acuáticos y flotantes.

Distancia entre dos puntos de un movimiento cíclico. 


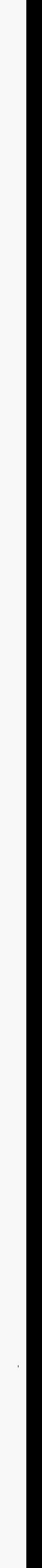


BIBLIOGRAPHY

71 

Aliki (1962). My Five Senses. New York, NY: Thomas Y. Crowell Company.

Alvin, Virginia, \& Silverstein, Robert. Smell, The Subtle Sense. Morrow.

Arnosky, Jim. Crinkleroot's Guide to Knowing the Trees. Bradbury.

Beame, R. (1975). What Happens to Garbage? New York, NY: Julian Messner. (Grade level: Upper grades.)

Billington, E. (1971). Understanding Ecology. New York, NY: Morrow. (Grade level: KAdult.)

Cone, Molly. Come Back, Salmon: How a group of dedicated kids adopted pigeon creek and brought it back to life. Sierra Club.

Cherry, Lynne. A River Ran Wild. Gulliver.

Earthworks \& Comp. (1989). 50 Simple Things You Can Do To Save the Earth. Berkeley: Earthworks. (Upper grades)

Ford, B. (1981). Alligators, Raccoons, and Other Survivors: The Wildlife of the Future. New York, NY: Morrow. (Grade level: Upper grades).

Gibbons, Gail. Recycle! A Handbook for Kids. Little Brown.

Glaser, Linda. Wonderful Worms. Millbrook.

Hoff, M. (1991). Our Endangered Planet: Rivers and Lakes. Minneapolis, MN: Lerner Publications. (Grade level: Upper grades). 
Holmgren, V. (1988). Owls in Folklore and Natural History. Santa Barbara, CA: Campra Press. (Teacher resource).

Johnstone, H. (1990). Facts on Domestic Waste and Industrial Pollutants. New York, NY: Franklin Watts. (Grade level: Upper grades.)

Kelly, M.A. A Child's Book of Wildflowers. Four Winds.

Kindersley, Dorling. Eyewitness Visual Dictionary of Plants.

Lauber, P. (1974). Too Much Garbage. Garrard. (Grade level: Upper grades.)

Maynard, Thane. Saving Endangered Mammals: A Field Guide to Some of the Earth's Rarest Mammals. Watts.

Milgrom, H. (1972). ABC of Ecology. New York: MacMillan. (Primary).

Muller Gerda. The Garden in the City. Dutton.

Patent, Dorothy Hinshaw. Nutrition: What's in the Food We Eat. Holiday House.

Pringle, L. (1975). Chains, Webs, and Pyramids: The flow of Energy in Nature. New York, NY: Crowell. (Grade level: Upper grades).

Rand, Gloria. Prince William. Holt.

Roop, Peter \& Connie. One Earth, A Multitude of Creatures. Walker.

Simon, Seymour. Our Solar System. Morrow. 
Tomblin, Gill. The Wild. Putnam.

Wilson, A. (1990). Look! The Ultimate Spot-the-Difference Book. (Grade level: K-Adult.)

Yolen, J. (1990). Birdwatch. New York, NY: Philomel Books. (Grade Level: K-Adult.)

Zolotow, Charlote. The Seashore Book. Harper Collins. 
